\title{
Institute of Advanced Legal Studies
}

School of Advanced Study

University of London

\section{Ronan Cormacain}

\section{Prerogative Legislation as the Paradigm of Bad Law- Making: The Chagos Islands}




\section{Prerogative Legislation as the Paradigm of Bad Law-Making: The Chagos Islands}




\section{Contents}

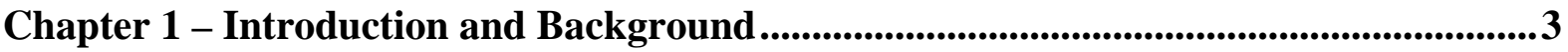

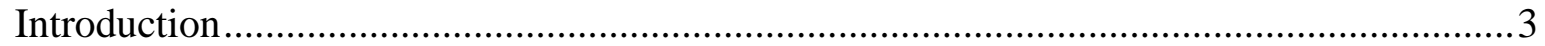

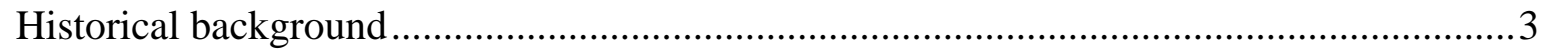

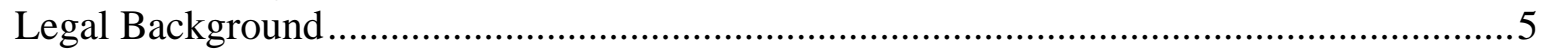

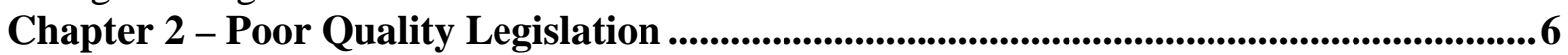

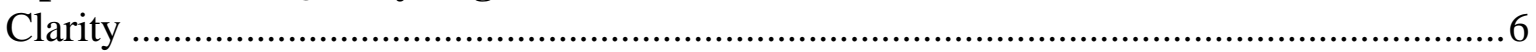

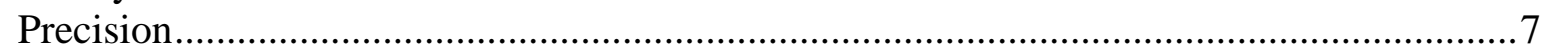

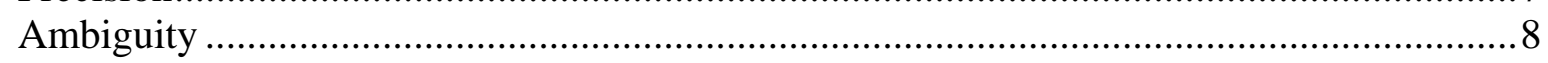

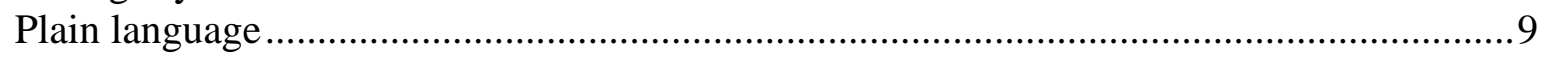

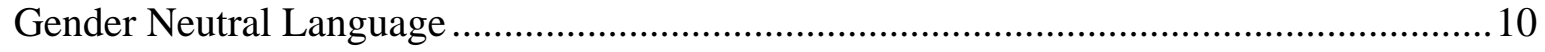

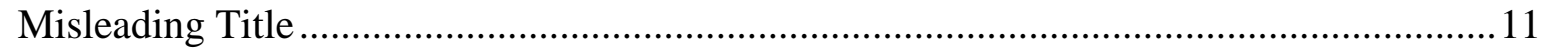

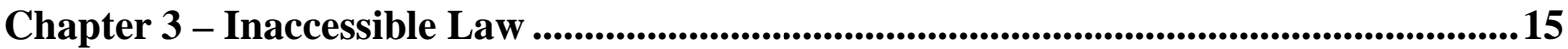

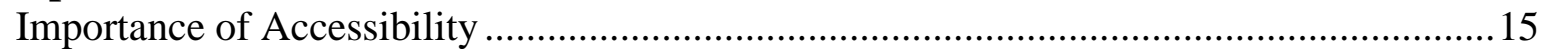

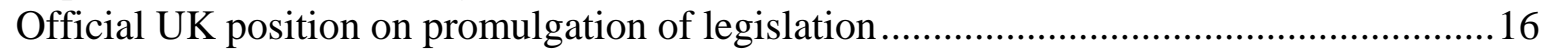

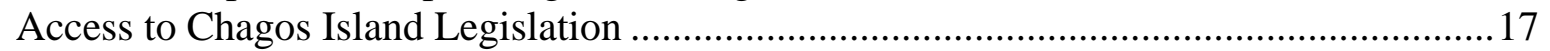

Chapter 4 - Use of Prerogative Powers to Make Legislation ..........................................20

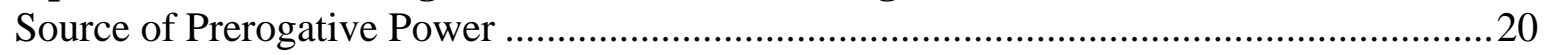

Nature, Extent and Justiciability of Legislative Prerogative Power ....................................21

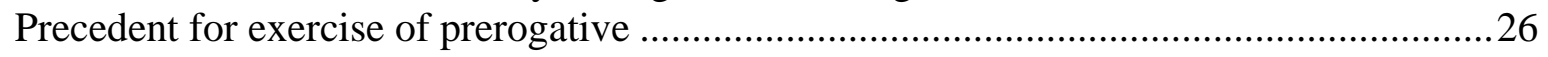

Subservience of Prerogative Legislation to Parliamentary Legislation...............................27

Extinguishment of Prerogative upon Establishment of Colonial Legislative Assembly .....30

Repugnancy of Colonial Legislation to English Law ....................................................... 31

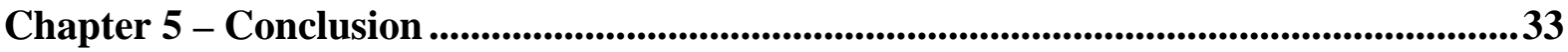

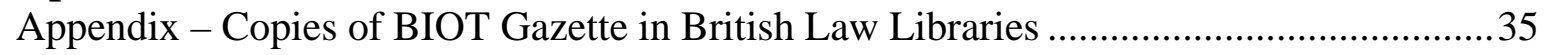

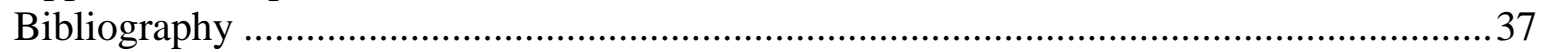

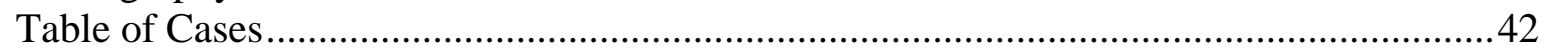

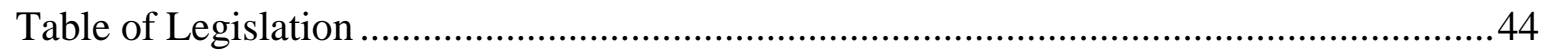

\section{Abbreviations}

BIOT British Indian Ocean Territory

FCO Foreign and Commonwealth Office 


\section{Chapter 1 - Introduction and Background}

\section{Introduction}

The Chagos Islands, a British Overseas Territory, are a small archipelago of coral atolls in the Indian Ocean. In 2004, Britain enacted the British Indian Ocean Territory (Constitution) Order 2004. Section 9 prohibited the Chagossians from living in the Chagos Islands. The 2004 Order was made by way of Royal Prerogative, which means that it was made by the Crown by Order in Council, following the advice of the Privy Council. In practice, this meant that it was made by the government without recourse to Parliament. The House of Lords ruled the 2004 Order valid in Bancoult (2). ${ }^{1}$

The hypothesis of this essay is that the 2004 Order is bad law because it is low quality, inaccessible and ultra vires. With regards to quality, I assess this by reference to Xanthaki's criteria of quality in legislation. ${ }^{2}$ For example, the Order is complex and uses archaic language. I also assess whether it can be called a ‘constitution' under Elkin's definition. ${ }^{3}$ Turning next to inaccessibility, I assess whether BIOT legislation is accessible under Donelan's definition of accessibility. ${ }^{4}$ I argue that the use of the Royal Prerogative meant that the Order was subject to minimal publicity. I also demonstrate the importance of accessibility by reference to judicial and academic opinion. I carry out empirical research on the locations where BIOT legislation is to be found and supplement this by a Freedom of Information request to the FCO.

Finally I argue that the Order is ultra vires the power of the Crown to make legislation for colonies. There are five reasons for this, which all relate to the nature of the prerogative power to legislate for colonies. (1) Prerogative legislation can only be made for peace, order and good government, and exile does not fall within this. (2) There is no precedent for the prerogative being used in this way. (3) The prerogative cannot subsist in the face of proper parliamentary legislation on the subject. (4) The prerogative power to legislate is extinguished by the establishment of a colonial legislature. (5) The 2004 Order is repugnant to Acts of Parliament. In order to prove this I analyse in detail the case law relating to the exercise of the prerogative.

An anti-democratic theme underlies many of the other points made in this essay. The 2004 Order is legislation without a legislature. It was not voted upon or assented to by the British Parliament. It was not the subject of a referendum among the Chagossians. It was not voted upon by any representatives of the Chagossians.

\section{Historical background}

At the outset, a word on nomenclature. The Chagos Islands / Archipelago is the geographical name for the islands. British Indian Ocean Territory is the name first used in 1965 to demarcate the islands as a political entity. Diego Garcia is the name of the largest island. Chagossians are the inhabitants. Ilois is the historic French / Creole name used to describe them ('people of the islands').

\footnotetext{
${ }^{1}$ Bancoult v Secretary of State for Foreign and Commonwealth Affairs [2008] UKHL 61

${ }^{2}$ Helen Xanthaki, 'On Transferability of Legislative Solutions: The Functionality Test' in Constantin Stefanou and Helen Xanthaki (eds), Drafting Legislation: A Modern Approach (Ashgate, 2008).

${ }^{3}$ Zachary Elkins et al, The Endurance of National Constitutions (Cambridge University Press, 2009).

${ }^{4}$ Edward Donelan, 'European Approaches to Improving Access to and Managing the Stock of Legislation' (2009) 30 SLR 147.
} 
The Chagos Islands were originally part of Mauritius. ${ }^{5}$ In 1814, Mauritius was ceded by the French to the British. By the 1960s the main economic activity on the islands was harvesting copra from coconut plantations. The population in the 1960s was low, between 829 and $1,500^{6}$. Some families had lived there for generations.

Storm clouds began to gather in 1964 when the UK discussed establishing a US military base on Diego Garcia. In 1965, the UK detached the islands from Mauritius. Agreement on the base was reached between the US and the UK in 1966. In 1967, the UK bought all land from the coconut plantation company. In 1968, Mauritius became independent. From 1968 to 1971, the Chagossians left the islands. Force was not used, although it was made clear to the islanders that there was to be neither employment nor supplies on the island. The

Chagossians moved to either Mauritius or the Seychelles. Their lives in those places were bleak. They were eventually paid a small amount of compensation.

Every single British judge who has considered the conduct of the British government towards the Chagossians in that period has condemned it. Sedley LJ in the Court of Appeal said that

What they have received has done little to repair the wrecking of their families and communities, to restore their self-respect or to make amends for the underhand official conduct now publicly revealed by the documentary record. ${ }^{7}$

In the House of Lords, Lord Hoffman stated 'the removal and resettlement of the Chagossians was accomplished with a callous disregard of their interests'. 8 Lord Rodger spoke of the 'unhappy - indeed in many respects disgraceful - events of 40 years ago' ${ }^{9}$ Lord Carswell spoke of 'distress and indignation'. ${ }^{10}$

The former UK Foreign Secretary Robin Cook called government action 'sordid and morally indefensible'. 11 Bruce Kent, co-founder of the Campaign for Nuclear Disarmament said 'it is a story of ruthless military and economic imperialism, Cold War driven, and underpinned by servile British governments'. ${ }^{12}$ Tomkins said it raised 'frankly grotesque issues of British colonial arrogance and high-handedness'.13

From the 1970s onwards, the Chagossians made efforts to argue for their right to return to their homeland. These were ultimately fruitless, although they were occasionally given permission for short visits, paid for by the British government. They received some further compensation. I attended a Freedom of Information Tribunal in London on 10/7/2012 at which Colin Roberts, Overseas Territories Director of the FCO stated in cross examination that 'government policy is to prevent resettlement of BIOT'.

\footnotetext{
${ }^{5}$ See further, David Vine, Island of Shame: The Secret History of the US Military Base at Diego Garcia (Princeton University Press, 2009).

${ }^{6}$ Adam Tomkins, 'Magna Carta, Crown and Colonies' (2001) PL 571, although Madeley puts it at up to 2000, John Madeley, Diego Garcia: A Contrast to the Falklands (Minority Rights Group Report No. 54, 1985).

${ }^{7}$ Bancoult (2) in the Court of Appeal.

${ }^{8}$ Bancoult (2), House of Lords [10].

${ }^{9}$ ibid [75].

${ }^{10}$ ibid [119].

${ }^{11}$ Vine, 171.

${ }^{12}$ Bruce Kent, Book Review: Diego Garcia Island of Shame (2009) accessed at < http://www.intellidatasystems.com/bkcms/> on 2/8/2012.

13 Tomkins, 572.
} 


\section{Legal Background}

Legislation authorised all government actions. The Chagossians responded with litigation challenging the validity of the legislation (and concomitant government actions). Some of this is digested below.

\section{British Indian Ocean Territories Order 1965}

This Order detached the Chagos Islands from Mauritius and established the British Indian Ocean Territories as a separate legal entity. BIOT consisted of the Chagos Islands together with some other unconnected islands (which were ultimately transferred to the Seychelles). It established a Commissioner with the power to make laws for the peace, order and good governance of the territory.

\section{Immigration Ordinance 1971}

This Ordinance was made under the 1965 Order. Section 4(1) stated that 'no person shall enter into the Territory ... or remain in the Territory' without a permit. It formed the legal basis for the exile of the Chagossians.

\section{Bancoult (1) 2000}

The Divisional Court in the UK gave a ruling in favour of the Chagossians. ${ }^{14}$ The court ruled that the Immigration Ordinance 1971 was void for being ultra vires.

Immigration Ordinance 2000

As soon as the judgement in Bancoult (1) was made, the government enacted the Immigration Ordinance 2000. This was largely the same as the 1971 Ordinance except that the prohibitions on entry did not apply to Chagossians ie they were legally entitled to move to the Chagos Islands (other than Diego Garcia).

British Indian Ocean Territory (Constitution) Order 2004, British Indian Ocean Territory (Immigration) Order 2004

These Orders were made in the face of suspected attempts by the Chagossians to launch a protest flotilla to land on the islands. They reversed the Immigration Ordinance 2000. Both Orders were made under the Royal Prerogative. The Constitution Order is the key Order and section 9 is the key provision. It states:

No right of abode in the Territory

9. - (1) Whereas the Territory was constituted and is set aside to be available for the defence purposes of the Government of the United Kingdom and the Government of the United States of America, no person has the right of abode in the Territory.

(2) Accordingly, no person is entitled to enter or be present in the Territory except as authorised by or under this Order or any other law for the time being in force in the Territory.

Bancoult (2) 2008

The Chagossians commenced litigation against the 2004 Order. They were successful at the Divisional Court ${ }^{15}$ and at the Court of Appeal. ${ }^{16}$ However, their case was rejected by the House of Lords and the 2004 Order held to be valid. ${ }^{17}$

\footnotetext{
${ }^{14}$ Bancoult v Secretary of State for Foreign and Commonwealth Affairs [2001] QB 1067.

${ }^{15}$ [2006] EWHC 1038 (Admin).
} 


\section{Chapter 2 - Poor Quality Legislation}

Xanthaki sets out useful criteria for assessing the quality of legislation. ${ }^{18}$ In this chapter, I assess the quality of the 2004 Order by reference to what may be termed her 'technical' drafting criteria (technical in the sense that they relate solely to the words on the page, not the broader aspects of quality). These are that legislation should be clear, precise and unambiguous. At a lower level of importance in Xanthaki's hierarchy, legislation should be written in plain and gender neutral language. This chapter also argues that the very title of the Order represents, in microcosm, its poor quality.

\section{Clarity}

Clarity means that legislation should be readily understandable. Citizens should be able to read it and quickly grasp its meaning. Butt condemned traditional drafting styles which 'ooze archaic language, complex grammatical structures and sentences of excruciating length'. ${ }^{19}$ Bennion advocates simplicity, which means 'to put into a form which is as clear (that is intelligible and free from elaboration) to the intended reader as is practicable' ${ }^{20}$ Lord Simon argued that 'people who live under the Rule of Law are entitled to claim that law should be intelligible'. ${ }^{21}$ Dickerson states that 'the importance of clarity to statutes needs little urging'.22 In Canada, the drafters take pride in the clarity of their legislation. ${ }^{23}$

The 2004 Order is not clear. Many of its provisions stretch on for lines and lines of text. Take section 3(2)(a) for example. It is 117 words long (not counting the additional words contained in paragraph (b)). It may be legally precise, but it borders on unintelligibility. It reads as follows:

(2) Without prejudice to the generality of sections 15, 16 and 17 of the Interpretation Act 1978 (as applied by section 2(1) of this Order) -

(a) the revocation of the existing Orders does not affect the continuing operation of any law made, or having effect as if made, under the existing Orders and having effect as part of the law of the Territory immediately before the commencement of this Order, but any such law shall thereafter, without prejudice to its amendment or repeal by any authority competent in that behalf, shall have effect as if made under this Order and be construed with such modifications, adaptations, qualifications and exceptions as may be necessary to bring it into conformity with this Order,

After carefully parsing this provision, I take it to mean two things. Firstly, that existing laws continue in operation after the 2004 Order is made. Secondly, that existing laws are to be

\footnotetext{
${ }^{16}$ [2008] QB 365.

${ }^{17}$ [2008] UKHL 61.

${ }^{18}$ Xanthaki (n 2).

${ }^{19}$ Peter Butt, 'Modern Legal Drafting' (2002) 23 SLR 12.

${ }^{20}$ Francis Bennion, 'The Readership of Legal Texts' (1993) 27 April, Clarity 1.

${ }^{21}$ Lord Simon, 'The Renton Report - Ten Years On' (1985) SLR 133.

${ }^{22}$ Reed Dickerson, 'The Diseases of Legislative Language' (1964) 1 Harv J on Legis 5, 5.

${ }^{23}$ Peter Johnson, 'Legislative Drafting Practices and Other Factors Affecting the Clarity of Canada's Laws' (1991) 12 SLR 1.
} 
treated as if they had been made under the 2004 Order. This could be redrafted more simply as -

(2) The revocation of the existing Orders does not affect the validity of any law made under those Orders.

(3) But any law made under the existing Orders has effect as if it were made under this Order.

This redrafting follows Del Duca's exhortation that 'the goal of simplification is to say exactly the same thing as the original but in simplified understandable language'. ${ }^{24}$

Another barrier to clarity is superfluous words or phrases. For example, section 2(2) sets out definitions to be used 'unless the contrary intention appears'. Nowhere in the Order does a contrary intention appear. This form of words in a definition provision is a classic drafting technique, but it is meaningless in this context - a ritual incanted to give weight, but lacking in substance.

Further superfluities exist. Section 3(2) refers to the Interpretation Act 'as applied by section 2(1) of this Order'. This adds nothing. As section 2 applied the Act, repetition in s. 3 is valueless.

Section 10 is 'subject to the provisions of this Order'. Again, this is verbiage. The Order is a single document, a single law to be read as a coherent whole. Every provision is subject to every other provision anyway. The phrase is redundant.

Other prerogative legislation suffers similar deficiencies. Some use textual amendments which are terse to the point that the reader can have no idea as to what change is being made or what the new law is, for example the Diplomatic Service (Amendment) Order 2009.

\section{Precision}

Precision means that legislation should have exact and precise boundaries. Christie makes an argument for open-textured or vague law, but I disagree. ${ }^{25}$ Readers need to know exactly what is lawful and unlawful. The Renton Report even put precision as more important than simplicity - 'the draftsman must never be forced to sacrifice certainty for simplicity'. ${ }^{26}$ The US Supreme Court stated that 'it is a basic principle of due process than an enactment is void for vagueness if its prohibitions are not clearly defined'. ${ }^{27}$

The 2004 Order is littered with vague provisions.

Section 2(1) states that the Interpretation Act 1978 applies to the Order with 'the necessary modifications' but does not specify what those modifications are. Section 3 talks of 'modifications, adaptations, qualifications and exceptions as may be necessary' to other laws, again without specifying what those are. Even beyond the vagueness, there is an internal inconsistency - is the 1978 Act only subject to modifications but not adaptations, qualifications and exceptions? It is unclear if a difference of meaning is intended. Section 3(1) revokes the 'British Indian Ocean Territory Orders 1976 to 1994'. There is a footnote to the reference number of one statutory instrument, a reference to a page number (of an unspecified book) and the name of a $3^{\text {rd }}$ Order. This is not precise. If legislation is to

\footnotetext{
${ }^{24}$ Louis Del Duca, 'Is it Time for a Model Set of Drafting Principles' (2000 - 01) 105 Dick L Rev $205,207$.

${ }^{25}$ George Christie, 'Vagueness and Legal Language’ (1963-64) Minn L Rev 885.

${ }^{26}$ Report of the Renton Committee on the Preparation of Legislation (1975, Cmnd. 6053), paragraph 11.5.

${ }^{27}$ Grayned v Rockford 408 US 104, 108 (1972)
} 
be revoked, the precise name and reference number of all legislation to be revoked should be specified. Instead, the Order has a garbled mixture of numbers and text.

Section 7 allows the Commissioner to terminate appointments 'as the Commissioner may think fit'. This is not a precise law: it is an invitation to administrative capriciousness. Hewart criticised this practice of giving wide administrative discretion to officials as being contrary to the rule of law. ${ }^{28}$

\section{Ambiguity}

Legislation is unambiguous if it can only have one meaning. Fraser argues that it is sometimes better to have ambiguity in law to allow for space for political debate. ${ }^{29}$ Although this may hold true in politics, I profoundly disagree when it comes to legislation. The law should only admit to one meaning. Gobbi argues that if a statute is ambiguous, one can look to international treaties on the subject, ${ }^{30}$ but in my view, the better starting point is to avoid ambiguity in the first place.

Once again, the 2004 Order fails when measured against this criterion.

Section 4 is entitled 'Establishment of office of Commissioner' and commences with 'there shall be a Commissioner'. The difficulty is that there is already a Commissioner for the Territory, originally established by the 1965 Order. Is there meant to be continuity between these Commissioners, or are they completely different entities? Does it actually mean 'there shall continue to be a Commissioner'? ${ }^{31}$ The Order is ambiguous, although the fact that Anthony Campbell Crombie remained in post as Commissioner before and after the Order commenced indicates that the Order intended there to be continuity. ${ }^{32}$

The same point pertains with the Official Stamp in section 6 of the 2004 Order. That section provides that 'there shall be an Official Stamp'. Does it mean that 'there shall continue to be an Official Stamp'? Or should the old stamp under the 1965 Order be destroyed?

There is further ambiguity in section 5 when it comes to describing what the Commissioner does. Sometimes it is 'powers and duties', or 'other functions', or 'do and execute all things'. Section 8, when describing other office holders mentions 'functions attaching to office'. Once again, this is ambiguous. Using a single term like 'functions' is clear, but confusion arises once different terms are introduced.

Section 8 also introduces the concept (without definition) of 'substantive holder' of an office. Section 4(2) mentions the officer holder and someone who many temporarily be designated as an office holder. Is 'substantive holder' meant to include the first category but not the second?

Throughout the 2004 Order, the Crown is empowered to do things. Sometimes the provision empowering the Crown includes the phrase 'through a Secretary of State', but on other occasions, the power does not include this qualification. Lack of consistency is a classic example of ambiguity. When the Crown disallows a law under section 11, this must be done through a Secretary of State. But when the Crown pardons a person under section 12, it could be read as the Crown's sole decision.

Finally, under s. 4, the Commissioner 'holds' office, but under s. 15(3) a public officer may hold or 'act' in an office. It appears that the Commissioner holds office but does not act in that office. In practice, that cannot be correct.

\footnotetext{
${ }^{28}$ Lord Hewart, The New Despotism (Ernest Benn, 1929).

${ }^{29}$ Graham Fraser, 'In Praise of Ambiguity’ (2000) Jan - Feb Policy Options 21.

${ }^{30}$ Mark Gobbi, 'Making sense of Ambiguity: Some Reflections on the use of Treaties to Interpret Legislation in New Zealand' (2002) 23 SLR 47.

${ }^{31}$ For example, 'there shall continue to be a registrar of companies' s. 1060 Companies Act 2006.

${ }^{32}$ See List of Commissioners of BIOT on <www.worldstatesmen.org> accessed 3/8/2012.
} 


\section{Plain Language}

Eagleson described plain language as 'clear, straightforward expression, using only as many words as are necessary. It is language that avoids obscurity, inflated vocabulary and convoluted sentence structure'. ${ }^{33}$ Kimble advocates its use in legislation ${ }^{34}$ as does Thomas. ${ }^{35}$ Watson-Brown thinks plain language is simply another tool in the drafter's age-old struggle to create intelligible legislation. ${ }^{36}$ Sullivan wants to make the statute book more accessible by using plain language. ${ }^{37}$ Tanner concluded that plain language techniques make legislation more intelligible. ${ }^{38}$ Mowat recommended a 'massive rewriting of old laws and a consistent commitment to plain language drafting of new legislation'. 39

Turnbull makes specific suggestions on plain language techniques to improve the quality of a draft. $^{40}$ Without repeating the entirety of his list here, I set out below the most egregious breaches of his guidelines in the 2004 Order.

The most obvious deficiency has already been mentioned in the context of clarity - long sentences. Short sentences are one of the most basic of plain language techniques and the 2004 Order fails dismally in this regard. I have already mentioned s. 3(2)(a) weighing in at 117 words. Section 15(2) is 130 words long. These are paragraphs masquerading as sentences. In an Order only 15 sections long, 18 sentences contain more than 50 words. The second paragraph of The Picture of Dorian Grey is a single sentence 119 words long. ${ }^{41}$ Oscar Wilde can pull this off: drafters can't.

A second plain language deficiency in the 2004 Order is in the use of archaic language. The following table sets out the instances of archaic words.

\begin{tabular}{ll}
\hline Word & Occurrences \\
\hline forthwith & 1 \\
thereto & 1 \\
thereafter & 5 \\
thereof & 1 \\
therewith & 1 \\
whereon & 1 \\
hereby & 5 \\
\hline
\end{tabular}

Having read through the recent annual volumes of statutory instruments, no prerogative order commences 'immediately' they all commence 'forthwith'. See for example the Public Appointmments (Amendment) Order 2009.

The third plain language deficiency is not as pronounced - it is dividing up provisions using numbered lists. The Order does divide up sections into subsections and paragraphs.

However, there is scope for more to be done. For example, section 10(2) deals with the validity of laws made by the Commissioner. It is 107 words long and concludes with 4

\footnotetext{
${ }^{33}$ Robert Eagleson, Writing in Plain Language (Commonwealth of Australia, 1990).

${ }^{34}$ Joseph Kimble, ‘Answering the Critics of Plain Language’ (Plain Language Association International, 2003).

${ }^{35}$ Richard Thomas, 'Plain English and the Law' (1985) SLR 139.

${ }^{36}$ Anthony Watson-Brown, 'Defining “Plain English” as an Aid to Legal Drafting' (2009) 30 SLR 85.

${ }^{37}$ Ruth Sullivan, 'Implications of Plain Language Drafting’ (2000) 22 SLR 145.

${ }^{38}$ Edwin Tanner, 'Legislating to Communicate: Trends in Drafting Commonwealth Legislation’ (2002) 24

Sydney L Rev 529.

${ }^{39}$ Christine Mowat, A Plain Language Handbook for Legal Writers (Carswell, 1998) 79.

${ }^{40}$ Mark Turnbull, 'Clear Legislative Drafting: New Approaches in Australia' (1990) 11 SLR 161.

${ }^{41}$ Oscar Wilde, The Picture of Dorian Grey (Penguin Classics, 2006).
} 
grounds on which a law may be invalid. Unfortunately these four grounds are in a long line of text divided only by 3 'ors'. The provision would read much better if a numbered list was used, ie each ground was numbered (a), (b), (c) and (d), and each ground started on a fresh line.

A fourth plain language deficiency is one which is not as readily obvious. Turnbull suggests keeping related words together. Watson-Brown is more specific. He was concerned with provisions which set out a rule and a set of conditions which must be satisfied before the rule is to be used. His plain language suggestion is to avoid 'front-loading' conditions ie to clearly state the rule first, and then state the conditions after. If the provision meanders through several conditions before reaching the rule, the reader can easily lose the narrative thread of the provision. As Cormacain opines 'It is difficult for readers to link the first part of the sentence to the last part of the sentence if they have to push their way through four conditions in the interim' ${ }^{42}$ Mackinlay refers to this more technically as 'syntactic discontinuity' - deliberate separation of two elements of the same phrase by insertion of another clause between them. ${ }^{43}$

This kind of syntactic discontinuity is present in section 7. Section 7 empowers the Commissioner to do 3 things: (a) create offices, (b) make appointments to those offices, and (c) terminate those appointments. However, before reaching the second and third power, the reader must first get though the conditions of 'subject to the provisions of any law for the time being in force in the Territory and to such instructions as may from time to time be given to him by Her Majesty through a Secretary of State'. The better plain language approach would be to first state the power and then to separately state the conditions for exercise of that power. Similarly, in section 14, the reader must get through 40 words before discovering the point of the section (that the Commissioner can sell land). The first 40 words deal with pre-conditions for this exercise of power.

One final instance of a plain language deficiency is poor organisation. Turnbull suggests that legislation should have coherence. In a seminal book on drafting, Lord Thring's fourth golden rule includes a requirement that temporary provisions should be separated and placed by themselves under separate headings. ${ }^{44}$ Transitional provisions are temporary provisions which govern the change from an old system to the new system. Thornton's advice is that 'such provisions may be important but they are of temporary concern and should not be scattered about in the substantive provisions'. ${ }^{45}$ Unfortunately, section 13(2) of the 2004 contravenes this. Alongside powers of the Chief Justice to direct the court to sit in the UK, are provisions on cases which started before commencement of the Order but are to be heard after commencement - this kind of transitional provision should be in a schedule.

\section{Gender Neutral Language}

Legislation is gender neutral if it formally and substantively applies equally to all genders. This essay does not seek to weigh up the arguments for and against gender neutral drafting. Rather, it proceeds on the basis that gender neutral drafting is a good thing. There is nothing radical in this. Schweikart supports it. ${ }^{46}$ In Australia it is argued that sexist language

\footnotetext{
${ }^{42}$ Ronan Cormacain, ‘A Plain Language Case Study: Business Tenancies (Northern Ireland) Order 1996’ (2012) The Loophole 33, 40.

43 Jana Mackinlay, 'Syntactic Discontinuity in the Language of UK and EU Legislation' accessed at $<$ http://www.esp-world.info/index.html> on 1/8/2012.

${ }^{44}$ Henry Thring, Practical Legislation: The Composition and Language of Acts of Parliament and Business Documents (John Murrary, 1902) 42.

${ }^{45} \mathrm{G}$ Thornton, Legislative Drafting (Butterworths , $4^{\text {th }}$ edition, 1996) 385.

${ }^{46}$ Debora Schweikart, 'Gender Neutral Pronoun Redefined’ (1998-99) 20 Women’s Rts L Rep 1.
} 
denigrates women. ${ }^{47}$ Hill argues in favour of gender neutral language in court. ${ }^{48}$ For Petersson the case for gender neutral language is so strong that she argues that old statutes should be revised to strip them of gendered language. ${ }^{49}$

This is not a dry esoteric point, it has a real impact on everyday life. In Bebb v Law Society ${ }^{50}$ it was argued that a woman was entitled to be admitted as a solicitor as a woman was a 'person' within the meaning of the law. The actual ruling of the Court of Appeal was that a woman was not a 'person'. 1

The 2004 Order is not gender neutral. References to the Commissioner are to 'he' and 'his' powers. The masculine is also used to refer to public officers. Basic gender neutral drafting techniques could solve these problems. Even the classical references to 'Her Majesty' can be made gender neutral by the simple expedient, used in New Zealand legislation, of referring instead to 'the Crown'.

\section{Misleading Title}

There are two objections to the title British Indian Ocean Territory (Constitution) Order. Firstly, 'British Indian Ocean Territory’ is disingenuous. Secondly, the Order isn’t a constitution.

An Act's title should reflect its contents. In researching the use of personalised Bill titles, Jones quotes a drafter as saying that 'a short title is meant to be a description of what is in the Bill' ${ }^{52}$ The title should be sober and neutral, not tendentious or controversial. In Scotland this is mandated by Standing Orders of the Scottish Parliament:

The text of a Bill - including both its short and long titles - should be in neutral terms and should not contain material that is intended to promote or justify the policy behind the Bill, or to explain its effect. ${ }^{53}$

\section{'British Indian Ocean Territory'}

In the indexes of the digested cases from Mauritius before BIOT was detached from it in 1965, there is no reference to an entity called BIOT. ${ }^{54}$ The term BIOT didn’t exist before 1965. Britain is responsible for 13 other Overseas Territories:

- Anguilla

- British Antarctic Territory

- Bermuda

- British Virgin Islands

\footnotetext{
${ }^{47}$ Unknown, ‘Avoidance of Sexist Language in Legislation’ (1985) 11 Commw L Bull 590.

${ }^{48}$ William Hill, 'A Need for the Use of Non-Sexist Language in the Courts' (1992) 49 Wash and Lee L Rev 275.

${ }^{49}$ S Petersson, ‘Gender Neutral Drafting: Recent Commonwealth Developments’ (1990) 20 SLR 35.

${ }^{50}$ [1914] 1 Ch 286.

51 Rosemary Auchmuty, 'Whatever happened to Miss Bebb? The Law Society and Women’s Legal History' (2011) 31 Legal Studies 199.

52 Brian Jones, 'Transatlantic Perspectives on Humanised Public Law Campaigns: Personalising and Depersonalising the Legislative Process’ (2012) 6 Legisprudence 57,70.

${ }^{53}$ Section 9.2.3.

${ }^{54}$ W Greene, Digest of the Reported Criminal Jurisprudence of the Supreme Court of Mauritius $1843-1883$ (Port Louis, 1884), L Hughes, Digest of the Reported Decisions of the Supreme Court of Mauritius 1861-1901 (Central Printing Establishment, 1905), G Nairac, Digest of the Mauritius Law Reports 1902-1925 (PG Bumstead, 1927), Gerard Lalouette, A Digest of the Decisions of the Supreme Court of Mauritius 1926 -1945 (Eliel Felix, 1947).
} 
- Cayman Islands

- Falkland Islands

- Gibraltar

- Montserrat

- Pitcairn Island

- St Helena, Ascension Island and Tristan da Cunha

- South Georgia and Sandwich Islands

- Sovereign Base Area on Cyprus

BIOT is an artificial construct. 'Chagos Islands' is precise and geographically accurate. BIOT is vague and insipid. Furthermore, BIOT gives the impression of some remote, unoccupied land, untouched by human hand and unnamed by human tongue. The only similarly named Overseas Territory is British Antarctic Territory - a place with no permanent inhabitants. Chagos Islands are peopled by Chagossians, but there is no obvious noun to describe the people who belong to BIOT.

It might be thought that this argument is a fanciful conspiracy theory. However, the propaganda drive of the UK when making the original 1965 Order was express (although covert). The government of the day deliberately misrepresented the facts to the outside world, pretending that the islands were only inhabited by a few migrant labourers. Vines cites the following comments by various senior British officials -

'The legal position of the inhabitants would be greatly simplified from our point of view - though not necessarily from theirs - if we decided to treat them as a floating population.'

'This device, though rather transparent, would at least give us a defensible position.' 'To certify, more or less fraudulently [the Chagossians] as belonging to somewhere else. ${ }^{55}$

This disingenuous approach is not limited to the colonial past. On 15 June 2004, the UnderSecretary of State for the FCO, Bill Rammell informed Parliament of developments in BIOT. He referred to the Chagossians who 'were in due course relocated to Mauritius and Seychelles, from where they or their families originated' ${ }^{56}$ This isn't actually a lie, but it certainly is misleading. 'Relocation' is a euphemism for the more accurate exiled / tricked / intimidated. A grandparent may have 'originated' in Mauritius, but many of the Chagossians were born and bred in the Chagos Islands. David Snoxell was the British High Commissioner to Mauritius when the 2004 Order was made, he described the actions of his own government as 'three decades of dissimulation and subterfuge'. ${ }^{57}$

Calling the Chagos Islands BIOT is as disingenuous as calling the UK the Eastern Atlantic Archipelago and as propagandist as naming it Airstrip One. ${ }^{58}$

\section{'Constitution'}

Finer describes constitutions as

\footnotetext{
${ }^{55}$ Vine, 91 for all quotes.

${ }^{56}$ Written Ministerial Statement 15 June 2004, col 32WS.

57 'Political Context (the Bancoult case) and Possible Solutions' (Colloquium: The Common Law, the Royal Prerogative and Executive Legislation, fCambridge, 19/1/2008).

${ }^{58}$ George Orwell, 1984 (Secker \& Warburg, 1949).
} 
Codes of rules which aspire to regulate the allocation of functions, powers and duties among the various agencies and offices of government, and define the relationship between these and the public. ${ }^{59}$

Elkins sets out three purposes of constitutions:

1. Limit the behaviour of government.

2. The symbolic function of defining the nation and its goals.

3. Defining patterns of authority and setting up government institutions. ${ }^{60}$

The 2004 Order does fulfil the third purpose as it does set out executive, legislative and judicial power structures.

The 2004 Order fails absolutely at the first purpose. This purpose can be traced back at least as far to Thomas Paine who said that the fundamental function of a constitution is to restrain government. $^{61}$ The Order does not grant rights to people over government, it simply exiles the people. Not quite Lincoln's paradigm of 'of the people, by the people, for the people ${ }^{62}$, rather it is government against the people. Another American perspective on British colonial constitutions is that 'Britain's history with its colonies shows it can and does sweep away rights when it is convenient'. 63 Plender stated that 'A significant number of modern national constitutions characterise the right to enter one's country as a fundamental or human right' ${ }^{64}$ But the only part of the 'constitution' which deals with human rights takes them away rather than protects them. As Lord Mance said 'a constitution which exiles a territory's inhabitants is a contradiction in terms'. ${ }^{65}$

The Order also fails at the second purpose. Murphy paraphrases this purpose thus, that it 'serves as a binding statement of a people's aspiration for themselves as a nation'. ${ }^{66}$ There is nothing in the 2004 Order which is uplifting or aspirational. Instead, there is the terse statement in section 9 that the territory was 'constituted and set aside for the defence purposes of the Government of the United Kingdom and the Government of the United States of America'. This is not a preamble but 'an apologia'. ${ }^{67}$ In addition, the apologia is simply wrong, as the former British High Commissioner to Mauritius said, 'I have never seen a convincing explanation as to why limited resettlement of UK nationals, on the Outer Islands, would pose a threat to the security of the base [Diego Garcia], 150 miles away' ${ }^{68}$

Not only does the 2004 Order fail as a constitution by the external standards set out above, it also fails by the government's own standards. Hendry and Dickson are two lawyers at the FCO. In their book, they state that

\footnotetext{
${ }^{59}$ S Finer, Five Constitutions (Humanities Press, 1979) 15.

${ }^{60}$ Elkins, (n 3).

${ }^{61}$ Common Sense and Other Writings (Modern Library, 2003)

62 Abraham Lincoln, Gettysburg Address, 1863.

${ }^{63}$ Michael Eshelman, 'New Pitcairn Islands Constitution: Strong, Empty Words for Britain’s Smallest Colony' (2012) 24 Pace Int’l L Rev 21, 23.

${ }^{64}$ Richard Plender, International Migration Law (2 ${ }^{\text {nd }}$ edition, Martinus Nijhoff, 1988) 135.

${ }^{65}$ Bancoult (2) [157].

${ }^{66}$ W Murphy, 'Constitutions, Constitutionalism and Democracy’ in Douglas Greenberg et al (eds) Constitutionalism and Democracy: Transitions in the Contemporary World (Oxford University Press, 1993).

${ }^{67}$ Bancoult (2) [150].

${ }^{68}$ Snoxell, 3.
} 
The policy of the UK Government has been to seek evidence of popular acceptance in the territory of a politically agreed [constitutional] text, whether by resolution of the locally elected body, by referendum, or by less formal means of public consultation. ${ }^{69}$

Far from being consulted, the Chagossians were kept in the dark about their forthcoming exile from their homeland.

The UK government discussed human rights in Overseas Territories and stated in a White Paper that 'Overseas Territories legislation should comply with the same international obligations to which Britain is subject, such as the European Convention on Human Rights and the UN International Covenant on Civil and Political Rights'. ${ }^{70}$ Hendry and Dickson discuss the White Paper and state that 'the UK's position was that it would not agree to a new territory constitution which did not contain a fundamental rights chapter'. ${ }^{71}$ Although this was true for the constitutions of the Virgin Islands, Cayman Islands, St Helena, Ascension and Tristan da Cunha, Pitcairn, Falkland Islands, Turks and Caicos Islands, Gibraltar and Montserrat, it isn't true for the Chagos Islands.

Contrast the treatment of the Chagos Islands with the treatment of Mauritius. The UK, by Order in Council under the Royal Prerogative, gave Mauritius a constitution in the Mauritius Independence Order 1968. That 1968 Constitution does comply with the requirements set out by Finer and Elkins. It commences with the phrase that 'Mauritius shall be a sovereign democratic state' and continues with 'the right of the individual to life, liberty and security of the person and the protection of the law'. There are 17 sections in the chapter entitled 'protection of the fundamental rights and freedoms of the individual'. There are chapters on citizenship, parliament, the executive, the judicature, the public service, the ombudsman and finance. That constitution is 122 sections long. It bears no comparison to the purported constitution contained in the 2004 Order. As Finer notes 'some [constitutions] are never meant to be taken seriously'. ${ }^{72}$

\footnotetext{
${ }^{69}$ Ian Hendry and Susan Dickson, British Overseas Territory Law (Hart Publishing, 2011) 31.

${ }^{70}$ Partnership for Progress and Prosperity: Britain and the Overseas Territories (Cm 4264, 1999).

${ }^{71}$ Hendry and Dickson, 151.

${ }^{72}$ S Finer et al, Comparing Constitutions (Clarendon Press, 1995) 6.
} 


\section{Chapter 3 - Inaccessible Law}

\section{Importance of Accessibility}

Donelan defines accessibility - 'in the context of legislation, means that it is easy to access online or in published texts'. 73

Accessibility is important for many reasons. Firstly, it is a fundamental component of the rule of law, 'the acceptance of the rule of law as a constitutional principle requires that a citizen, before committing himself to any course of action, should be able to know in advance what are the legal consequences that will flow from it'. ${ }^{74}$ Secondly, it is elementary fairness that people are told of the rules they are expected to obey. Thirdly, it grants democratic legitimacy to law. Carr said that laws should be published 'so that the public, in being informed of its ante-natal opportunity to criticise and the place where copies of the proposed rules can be obtained, is indirectly informed that legislation is impending' ${ }^{75}$ Fourthly, it acts as a check upon executive abuse of power. Ronald, discussing executive legislation, regarded 'publicity as a safeguard for holding the rule-making officials in check' ${ }^{76}$ Finally, in practical terms, it increases the chance of a law being obeyed.

In elucidating the meaning of the rule of law, Bingham begins with 'accessibility of the law'. ${ }^{77}$ Greenberg says that 'it is of enormous importance that laws are made accessible to the public as soon as possible'. ${ }^{78}$ The European Court of Human Rights stated that 'the law must be adequately accessible'. ${ }^{79}$ In Australia, Gleeson said that 'the content of the law must be adequately accessible'. ${ }^{80}$ In the European Union, the same point is made by Donelan 'all participants in a society, an economy or government need to be able to find the legislation' ${ }^{81}$ The SIGMA initiative reinforces this point for Europe - 'a principal aim of legislation is to enable those affected by it to organise and regulate their activities in accordance with its normative requirements ... ready access to that legislation is a necessary concomitant' ${ }^{82}$ The courts in Canada take the same view 'to bind the citizen by a law, the terms of which he has no means of knowing, would be a mark of tyranny'. ${ }^{83}$ Canadian drafter Keyes agrees, 'if the law is to command respect and function as it is intended, it must be adequately promulgated' ${ }^{84}$

In New Zealand, the subject is of such importance that the government created the Public Access to Legislation project. ${ }^{85}$ Anthony says this was done 'to improve the way in which New Zealand legislation is made available to the public' ${ }^{86}$

\footnotetext{
73 Donelan, 182.

${ }^{74}$ Black Clawson v Papierwerke Waldhof (1975) AC 591, 638,

${ }^{75}$ Cecil Carr, Delegated Legislation (Cambridge University Press, 1921) 36.

${ }^{76}$ James Ronald, 'Publication of Federal Administrative Legislation’ (1938) 7 Geo Wash L Rev 52, 61.

77 Tom Bingham, The Rule of Law (Penguin, 2011) 37.

${ }^{78}$ Daniel Greenberg, Craies on Legislation ( $9^{\text {th }}$ edition ,Sweet and Maxwell, 2008) 374.

${ }^{79}$ Sunday Times v UK (1979) 2 EHRR 245, 271.

${ }^{80}$ Murrary Gleeson, 'Courts and the Rule of Law' (Melbourne University, 7 November 2001).

${ }^{81}$ Donelan, 149.

${ }^{82}$ SIGMA, Law Drafting and Regulatory Management in Central and Eastern Europe SIGMA Papers no. 18.

${ }^{83}$ Watson $v$ Lee (1979) 26 ALR 461, 465.

${ }^{84}$ John Mark Keyes, 'Perils of the Unknown - Fair Notice and the Promulgation of Legislation' (1993) 25

Ottawa L Rev 579, 606.

${ }^{85}$ Geoff Lawn, 'Improving Public Access to Legislation: The New Zealand Experience so far’ (2004) 6 UTS L Rev 49.

${ }^{86}$ Kate Anthony, 'The Public Access to Legislation Project: Served with Accompaniments' (2008) 16 Austl L Libr 21, 21.
} 
The specific issue of access to legislation has come before the UK courts twice recently. In $R$ $v$ Chambers ${ }^{87}$ the defendant only avoided a criminal conviction when it was realised, at the last moment, that he was being prosecuted under a long-revoked law. The court found it troubling that the case had advanced so far on foundations of straw. It bemoaned the fact that 'there is no comprehensive statute law database with hyperlinks which would enable an intelligent person, by using a search engine, to find out all the legislation on a subject' ${ }^{88}$ The legislation in that case was at least available online, albeit that it was lost amidst a welter of other regulations. The issue in $Z L$ and $V L$ was more concerned with the lack of publication of the statute. ${ }^{89}$ An Act received Royal Assent on 7 November 2002 and came into force immediately. Before being printed on the 28 November, the government attempted to use the Act against ZL and VL. The Court of Appeal found in favour of the government 'it is beyond argument that an Act of Parliament takes legal effect on the giving of Royal Assent, irrespective of publication'. ${ }^{90}$ However, the court was critical of the government's approach and warned that it was not guaranteed of success the next time. It left open the question on 'a consideration of the validity of the exercise of executive powers which invade a Convention right in reliance on an inaccessible law'. ${ }^{91}$

\section{Official UK Position on Promulgation of Legislation}

What then is the official position in the UK on the promulgation of legislation? Greenberg cites two parliamentary statements on the subject. Firstly, the Attorney General

The Lord Chancellor recognises that he has a responsibility, on behalf of the government, to ensure that satisfactory arrangements are made for the publication of the statute book, in order that the citizen may know by what laws he is bound. ${ }^{92}$

Secondly, in response to the ZL case, the House of Lords stated that 'all Acts are published simultaneously on the internet and in print as soon as possible after Royal Assent'. 93 It is more difficult to ascertain the official position on promulgation of prerogative legislation. Greenberg states that it is available from two sources. Firstly, as prerogative orders are made on the advice of the Privy Council 'they are however readily available from the Privy Council'. ${ }^{94}$ Secondly, even though they aren't statutory instruments within the meaning of the Statutory Instruments Act 1946, 'some are also printed at the end of the annual volumes of statutory instruments published by Her Majesty's Stationery Office. ${ }^{95}$ In correspondence, the Statutory Publications Office in Northern Ireland have stated that prerogative orders relating to Northern Ireland are also included in the annual volumes of Statutory Rules, even though they aren't actually statutory rules within the meaning of the Statutory Rules (Northern Ireland) Order 1979.96

\footnotetext{
${ }^{87}$ [2008] EWCA Crim 2467.

${ }^{88}$ Chambers, [28].

${ }^{89}$ ZL and VL $v$ Secretary of State [2003] EWCA Civ 25.

${ }^{90} Z L,[17]$.

${ }^{91} Z L$, [23].

${ }^{92}$ HC Deb. June 131991 WA 613-614.

${ }^{93}$ HL Deb February 10, 2003 cc 464-466.

${ }^{94}$ Greenberg, 390.

${ }^{95}$ Greenberg, 390.

${ }^{96}$ Email from Christine Scott to author (15/7/2012).
} 


\section{Access to Chagos Island Legislation}

It is immediately obvious to anyone researching Chagos Island legislation that it is extremely difficult to access. Tomkins describes it as 'unaccountable, indeed wholly secret rulemaking, ${ }^{97}$

There is no official website with authoritative copies of the legislation. The official government website for legislation has a small number of BIOT statutes, but none made under the Royal Prerogative (and the prerogative orders, including the 2004 Order are the key texts). The FCO, as the official government body responsible for Overseas Territories don't have the 2004 Order on its website. National Archives have some BIOT Gazettes (see further below), but none from 1990 onwards. ${ }^{98}$ Although Greenberg suggests that prerogative orders are readily available from the Privy Council, the reality is not quite as rosy. In correspondence, the Privy Council stated that

On our website Privy Council meetings from June 2010 include links to the full texts of Orders made that are not otherwise published on the legislation.gov.uk website. Unfortunately we do not have the staff resources to do this retrospectively, and inquirers are advised to contact us direct if they require copies. ${ }^{99}$

If one knows the date an order is made, the Privy Council will promptly send it out. However, if one doesn't know the date and name of an order and is just doing a generalised search, it is difficult to get anything.

The other source that Greenberg gives as a possibility is the annual volume of statutory rules. Again, this draws a blank for BIOT prerogative Orders. The 2004 volume of statutory instruments is 10,236 pages long. It doesn't contain the 2004 Order. There are some entries relating to Overseas Territories, but these relate to 'proper' statutory instruments ie those made in the proper way under the authority of (and subject to the scrutiny of) parliament. The original 1965 Order likewise doesn't appear in the 1965 volume of statutory instruments. In fact, it is noticeable by its absence, as the 1965 volume does contain other prerogative orders in council. For example, it has the Royal Instructions relating to BIOT, as well as prerogative orders relating to Fiji, Basutoland and Mauritius.

I submitted a request to the FCO under the Freedom of Information Act 2000 on 11/7/2012. The request concerned promulgation of BIOT legislation. In response the FCO claimed that Freedom of Information did not extend to Chagos Islands and that therefore they were not bound to answer any questions. This is in spite of the fact that BIOT legislation is made by the Queen, in right of the United Kingdom, in the United Kingdom after being drafted in the United Kingdom by United Kingdom civil servants. To give credit to the FCO, they did provide me with some information on a concessionary basis.

The one place that BIOT legislation is published is in the British Indian Ocean Territory Gazette. Once again, the Gazette isn't available online. According to the FOI response from the FCO, the current total global distribution list of the Gazette is 20. Of these, 16 go to an emanation of the government. The remaining 4 on the list are all British law libraries: The British Legal Library, Bodleian Law Library, Squire Law Library and the Library at the Institute of Advanced Legal Studies. One copy does go to Mauritius, but it is to the British High Commission there.

Richard Dunne and I have catalogued the holdings at these libraries other than the Bodleian. The results are set out in the Appendix. In summary, between 1965 and 1992, these holdings

\footnotetext{
97 Tomkins, 573.

98 Email from Dr Edward Hampshire to author (27/7/2012).

${ }^{99}$ Email from Margaret Newell to author (6/8/2012).
} 
are virtually non-existent. After 1992, these holdings are largely complete, although there are several missing volumes. The librarian at the Institute of Advanced Legal Studies stated that if they don't receive a copy, they contact the supplier, 'we are not always successful and we do not always know the reason why'. ${ }^{100}$ If these law libraries, on the FCO distribution list, don't have the legislation, how can anyone be expected to access it? In response to complaints about the lack of Gazettes at these libraries, the FCO replied 'the material you request should be in the public domain (even if for reasons beyond the control of present members of the BIOT Administration it is not)'. ${ }^{101}$

There are few non-governmental sources of BIOT Orders. Westlaw has none of the key BIOT Orders. Lexisnexis is only marginally better. Raworth's Constitutions of Dependencies and Territories lists 3 Orders, but the 2002 edition doesn't have the key 1965 Order or the 1971 Immigration Ordinance. ${ }^{102}$ The top ranked Google search result for the 2004 Order gives a text which has spelling and grammatical mistakes as well as missing out a section. It has only been through making personal contact with the legal team for the Chagossians that I was eventually able to get a full list of the statutes.

Even Parliament cannot ensure they have proper access to BIOT legislation. The FCO had previously indicated that they would send draft copies to the Foreign and Commonwealth Affairs Committee in advance of them being made. However, no draft copies of the 2004 Order were sent to the Committee. The Secretary of State for the FCO attempted to justify this to the Committee - 'we needed to preserve complete confidentiality if we were to avoid the risk of an attempt by the Chagossians to circumvent the Orders before they came into force'. ${ }^{103}$

By way of historical comparison, access to legislation was much better before BIOT was detached from Mauritius. Colonial Government $v$ Vitry (1899) concerned the promulgation of an 1898 Ordinance. ${ }^{104}$ The Ordinance was published in the Official Gazette and also in eight newspapers. The court held that this 'was sufficient publication under our law, and consequently, that this Ordinance came into force on the last mentioned day and hour [of the final publication]'. 105

It could be thought that the lack of official promulgation of this legislation is accidental. However, it is clear that official government policy is to make the BIOT legislation inaccessible. The Secretary of State sent a confidential telegram to the Governor of the Seychelles on the subject of what was to become the Immigration Ordinance 1971. In paragraph 3 he stated 'our concern is that publication of Ordinance and any regulations thereunder should be limited to minimum by law so as to attract as little attention as possible'. ${ }^{106}$ The Governor responded 'Ordinance would be published in BIOT Gazette which has only very limited circulation both here and overseas after signature by Commissioner. Publicity will therefore be minimal'. ${ }^{107}$

Other prerogative legislation is equally difficult to track down. The legislation governing the Northern Ireland Civil Service is the Civil Service Commissioners (Northern Ireland) Order 1999 as amended in 2003 and 2007. It is extremely difficult to access an up to date version of the 1999 Order. In fact, it is extremely difficult to even find out that there is an Order and

\footnotetext{
${ }^{100}$ Email of 30/8/2012 from Lesley Young to author.

${ }^{101}$ Email of 11/11/2010 from FCO to Richard Dunne.

102 Philip Raworth, Consitutions of Dependencies and Territories (Oceana, 2002).

103 Jack Straw letter of 9 July 2004.

${ }^{104}$ Reported in the 1861-1901 Mauritian Digest at 53.

105 Paragraph 14.

106 Telegram of 22/12/1970.

107 Telegram of 11/1/1971.
} 
that it was amended in 2003 and 2007. The Commissioners don't publish all the Orders. The official government websites don't have them. The official government printers and newspapers of record don't have them. Commercial databases don't have them.

Whether deliberate or accidental, it is well nigh impossible to access authentic copies of BIOT legislation and this makes the legislation fundamentally bad law. Millennia ago Suetonius wrote the following of Caligula's laws

These taxes being imposed, but the act by which they were levied never submitted to public inspection, great grievances were experienced from the want of sufficient knowledge of the law. At length, on the urgent demands of the Roman people, he published the law, but it was written in a very small hand and posted up in a corner so that no one could make a copy of it. ${ }^{108}$

In the internet age, publication via the Gazette is the equivalent to written in a very small hand and posted up in a corner.

${ }^{108}$ Suetonius, Lives of the 12 Caesars (Alexander Thomson translator, 1883) 278. 


\section{Chapter 4 - Use of Prerogative Powers to Make Legislation}

In this chapter, I argue that the 2004 Order is void as it goes beyond the prerogative powers to enact legislation. I begin by elucidating the source of the prerogative to legislate. I then set out five separate reasons why the exercise of this power is void.

Firstly, the nature of the power is to legislate for peace, order and good government of the territory. Exiling the inhabitants cannot be said to be for this purpose. Secondly, the prerogative is a creature of precedent and can only be used in a particular fashion if there is a precedent for it having been so used in the past. No such precedent exists. Thirdly, the prerogative is a residual power and cannot subsist if Parliament has already legislated upon a subject. Parliament has already so legislated and therefore the prerogative is in abeyance. Fourthly, the prerogative power to legislate for a conquered territory ends when that territory receives a legislative assembly of its own. The establishment of the Mauritian assembly ended the power to legislate. Finally, according to the Colonial Laws Validity Act 1865, prerogative powers cannot be used to legislate in a way which is repugnant to an Act of Parliament. The 2004 Order is repugnant both to Magna Carta and the Human Rights Act 1998.

These safeguards have been developed over the centuries by both courts and Parliament. They represent a defence against the capricious exercise of executive power untrammelled by democratic scrutiny.

\section{Source of Prerogative Power}

The Lord Chancellor defined prerogative power as the power 'to exercise authority in the name of the Monarch without the people and their elected representatives in Parliament being consulted'. ${ }^{109}$ Its historical justification could prove slightly embarrassing for modern democrats. Writing in 1680 Sir Robert Filmer stated that 'I have endeavoured to show the natural institution of regal authority, and to free it from subjection to an arbitrary election of the people'. ${ }^{110}$ Although all prerogative powers are nominally exercised by the Crown, Dicey states that prerogative acts 'though carried out in the King's name, are in truth wholly the acts of the Ministry'. ${ }^{111}$

The Public Administration Committee in the House of Commons listed many prerogative powers, including: making treaties, conducting diplomacy, deployment of armed forces, grant of pardons etc. ${ }^{112}$ Perreau-Sausinne thinks that even 'English constitutional lawyers disagree on what these rules are'. ${ }^{113}$ Turpin argues that 'a strong case can be made for replacing all the rather ill-defined and wide-ranging powers that currently rest on the prerogative with a statutory code'. ${ }^{114}$

Prerogative legislation is one of the most important remaining prerogative powers. It is made by the Crown on the advice of the Privy Council (a body made up of senior government and establishment figures) but without the involvement of Parliament. Prerogative legislation is

\footnotetext{
${ }^{109}$ Department of Justice, The Governance of Britain (Cm7170, 2007) 15.

${ }_{110}$ Andrew Browning, English Historical Documents Vol VIII ( Eyre \& Spottiswoode, 1953).

${ }^{111}$ AV Dicey, Introduction to the Study of the Laws of the Constitution (8 ${ }^{\text {th }}$ edition, 1915) 422.

112 Select Committee on Public Administration, Taming the Prerogative (HC 2003-04, 422),

${ }^{113}$ Amanda Perreau-Sausinne, 'British Acts of State in English Courts' (2007) 78 BYIL 176, 177.

${ }^{114}$ Colin Turpin and Adam Tomkins, British Government and the Constitution (Cambridge University Press, 2007) 467.
} 
increasingly uncommon and indeed anachronistic. ${ }^{115}$ Historically it has been used for diverse purposes. For example, economic warfare in the First World $\mathrm{War}^{116}$ and to requisition ships in the Falklands War. ${ }^{117}$ It was used to regulate the Civil Service in England and Wales. It is still used to regulate the Northern Ireland Civil Service, although this is under pressure from the Civil Service (Special Advisers) Bill currently before the Northern Ireland Assembly. Poole describes it as the 'black sheep' of the constitutional fold as the prerogative is 'far removed from the modern archetype of legitimate lawmaking'. 118 The Constitutional Reform and Governance Act 2010 sought to remove many prerogative powers and replace them with fully democratic ones (for example putting the Civil Service on a statutory footing). Warbrick notes that there was nothing in that Act to remove prerogative powers in relation to colonies, and with specific reference to Diego Garcia finds this 'a particularly troublesome conclusion in the light of the way the power has sometimes been used in the past'. 119

For the purposes of this essay, the most important prerogative power to enact legislation is the power to legislate for colonies. Even this is fading. According to the Foreign Affairs Committee, only Gibraltar and BIOT are now governed by the prerogative, all other Overseas Territories are governed by statutes subject to Parliamentary scrutiny. ${ }^{120}$

Holdsworth makes a critical distinction on the nature of legislative power depending upon whether the territory was settled, or whether it was conquered or ceded. In settled territories 'the colonists had all the constitutional rights of Englishmen'. ${ }^{121}$ This meant that, as explained in Blankard v Galdy (1696) 'all laws in force in England are in force there', ${ }^{122}$ ie they were subject to the rule of Parliament, not to the rule of the Crown under the prerogative. However, in the case of conquered or ceded territories, the Crown has full prerogative powers to legislate. The key case of Campbell $v$ Hall (1774) explained that 'the King has a right to a legislative authority over a conquered country' ${ }^{123}$ Roberts-Wray agrees with this distinction between settled and conquered / ceded territory. ${ }^{124}$

Although there may be an historical reason for treating settled and conquered territory differently, it is harder to see a moral one. Why should Chagossians be subject to unscrutinised prerogative legislation simply because Mauritius was ceded from the French in 1814 rather than being settled by the British in 1814? Tomkins argues that the law should not be dependent on such 'ancient and formal niceties'. ${ }^{125}$

\section{Nature, Extent and Justiciability of Legislative Prerogative Power}

It is accepted on all sides that there is a prerogative power to legislate for conquered territories. What then is its nature and extent? Is this power justiciable? It is submitted that the nature of the power is a power to legislate for the peace, order and good governance of

\footnotetext{
${ }^{115}$ Richard Moules, 'Judicial Review of Prerogative Orders in Council’ (2009) CLJ 14, 14.

${ }^{116}$ Reprisal Orders 1915, 1917.

${ }^{117}$ Requisition of Ships Order 1982

${ }^{118}$ Thomas Poole, 'United Kingdom: The Royal Prerogative’ (2010) 8 IJCL 146,147.

${ }^{119}$ Colin Warbrick, 'Who Calls the Shots? Defence, Foreign Affairs, International Law and the Governance of Britain’ 548, in Mads Andenas \& Duncan Fairgrieve (eds)Tom Bingham and the Transformation of the Law: A Liber Amicorum (Oxford University Press, 2009).

${ }^{120}$ Foreign Affairs Committee, Seventh Report: Overseas Territories (HC 2007-08, HC 147-I) para 28.

${ }^{121}$ William Holdsworth, A History of the Law of England Volume XI (Methuen, 1938) 234.

1221 Salk 411, 412.

1231 Cowp. 204.

${ }^{124}$ Kenneth Roberts-Wray, Commonwealth and Colonial Law (Stevens \&Sons, 1966).

125 Tomkins, 579.
} 
the territory. It is submitted that this power is limited, not absolute. Finally, it is submitted that the power is justiciable.

\section{Nature of Power}

Determining the nature of the power is not easy. Prerogative power by definition, exists beyond statutory power. However, prerogative legislation and case law do provide some assistance.

In s. 15(1) of the 2004 Order, the following power is reserved to the Crown 'to make laws for the peace, order and good government of the Territory'. The same formulation appears in s. 19 of the 1965 Order and s. 15 of the British Overseas Territory Order 1976. Parliaments in Northern and Southern Ireland were originally given power 'to make laws for the peace, order and good government' (although this relates to power of a legislature rather than the prerogative). ${ }^{126}$ Section 2 of the British Settlements Act 1887 gave the Crown power to make laws 'for the peace, order and good government of Her Majesty's subjects'. It is submitted that the repetition of this mantra indicates that this is the definition of the prerogative power to legislate.

This view is in accordance with the judicial view. Carswell states that 'the orders had to be laws made for the peace, order and good government of the colony ${ }^{127}$ and Bingham agrees. ${ }^{128}$ Mance states that 'the British Settlements Act 1887 suggests that this phrase reflects the generally understood nature of such powers' ${ }^{129}$ Elliot and Perreau-Sausine go so far as arguing that the existence of a purpose for which such powers must be exercised means that prerogative orders are secondary rather than primary legislation. ${ }^{130}$ I think this fails to appreciate the status of prerogative legislation as 'original' in the sense that it is made as of right, rather than being delegated legislation dependent upon a primary statute to give it authority.

\section{Extent of Power}

The orthodox view was set out by Hoffman in Bancoult (2) when he said that 'the words "peace, order and good government" have never been construed as words limiting the power of a legislature'. ${ }^{131}$ Union Steamship Co of Australia $v$ King makes the same point 'a power to make laws for the peace, order and good government of a territory is as ample and plenary power as the power possessed by the Imperial power itself. That is, the words "peace, order and good government" are not words of limitation'. ${ }^{132}$

Several other authorities are in line with this. In $R v$ Burah $^{133}$ it was held that the Indian Parliament had plenary powers of legislation. In Hodge $v R^{134}$ it was held that the Ontario Parliament had authority as plenary as the Imperial Parliament. In Ibralebbe $v R^{135}$ it was held that powers for peace, order and good government connoted the widest lawmaking powers appropriate to a sovereign.

Running through all these cases is the notion of plenary power, ie full power to legislate. However, the critical distinction to be made is between 'plenary' and 'absolute'. The

\footnotetext{
${ }^{126}$ S. 4, Government of Ireland Act 1920.

127 ibid [127].

${ }^{128}$ Bancoult (2) [107].

129 ibid [144].

${ }^{130}$ Mark Elliot \& Amanda Perreau-Sausinne, 'Pyrrhic Public Law: Bancoult and the Sources, Status and Content of Common law Limitations on Prerogative Power’ (2009) PL 697.

131 ibid [50]

132 (1988) 166 CLR 1, 10.

133 (1883) 9 App Cas 889.

134 (1883) 9 App Cas 117.

135 [1964] AC 900.
} 
minority strand of jurisprudence argues that the power is not absolute, but limited. In a second Australian case, the Court of Appeal of New South Wales ruled that peace, order and good government does not

confer unlimited legislative power ... The words, by their very terms, confine the powers conferred to "peace, welfare and good government" ... The words convey plenary or sovereign power [but] does not necessarily import that the power is unlimited in scope. ${ }^{136}$

The Divisional Court in Bancoult (1) found this reasoning persuasive. It ruled that

The "peace, order and good government" of any territory means nothing, surely, save by reference to the territories population. They are to be governed not removed ... I cannot see how the wholesale removal of a people from the land where they belong can be said to conduce to the territory's peace, order and good government. ${ }^{137}$

Sales, counsel for the Crown in Bancoult (1), indicated that he thought this too narrow a definition. ${ }^{138}$ However, in Bancoult (2) the Court of Appeal agreed with the limitation, 'by exiling the population it has sought to do something which not only does not relate to the peace, the order or the good government of the Chagos Islands but which is antithetical to those ends'. ${ }^{139}$ Calvert, writing in the context of legislative competence for the Parliament of Northern Ireland is of the same opinion. ${ }^{140}$ Although in the constitutional cases of Gallagher $v$ Lynn, ${ }^{141}$ Ulster Transport Authority $v$ James Brown ${ }^{142}$ and Duffy $v$ Minister of Labour and National Insurance ${ }^{143}$ no argument was raised on the extent of peace, order and good government, this does not mean that the power is limitless. Calvert states that 'it is plain that he [Lord MacDermott in Duffy] is not using the word "general" here as synonymous with either "comprehensive" or "limitless" , 144

It is submitted that basic logic means that the power is limited. In order to grant an absolute power, simply draft that 'a person may do $X$ '. In order to grant a limited power, draft that 'a person can do $\mathrm{X}$ for $\mathrm{Y}$ purposes'. The absolutist view requires the words 'power to legislate for peace, order and good government of the territory' to actually mean 'power to legislate'. This is a logical fallacy and presupposes that all the previously cited definitions of prerogative power are simply verbiage. Unsurprisingly, courts take the view that legislative words are used for a purpose and are not verbiage. Bennion writes that 'it is to be presumed that (except so far as the contrary is evident) that it [the enactment] was competently drafted'. ${ }^{145}$ The courts agree 'words are used in an Act of Parliament correctly and exactly and not loosely and inexactly'. ${ }^{146}$

\footnotetext{
${ }^{136}$ Building Construction Employees and Builders' Labourers Federation of New South Wales v Minister for Industrial Relations (1986) 7 NSW LR 372, 383.

137 Bancoult (1) [57].

${ }^{138}$ Philip Sales, 'Bancoult (2) and Legitimate Expectation'(Colloquium: The Common Law, the Royal Prerogative and Executive Legislation ,Cambridge, 19/1/2008).

139 [2008] QB 365, 402.

${ }^{140}$ Harry Calvert, Constitutional Law in Northern Ireland: A Study in Regional Government (Stevens \& Sons, 1968).

${ }^{141}$ [1938] NI 21.

142 [1953] NI 79.

143 [1962] NI 6.

${ }^{144}$ Calvert, 170.

145 Francis Bennion, Bennion on Statutory Interpretation (5 ${ }^{\text {th }}$ edition, Lexisnexis 2008).

${ }^{146}$ Spillers v Cardiff Assessment Committee [1931] 2 KB 21, 43.
} 
The majority of the House of Lords in Bancoult (2) made a further fundamental mistake in interpreting the power to legislate for peace, order and good government of the Territory. This was to ignore the element of 'of the Territory'. As argued above, these words were deliberately inserted and therefore must be interpreted as having a meaning. However, Hoffman stated that the Crown 'will act in the interests of her undivided realm'. ${ }^{147}$ In fact, under the government's case, the Crown could also act in the defence interests of its close ally the US. So the words 'of the Territory' are mangled to mean 'of the Territory, or of any other territories governed by the Crown, or any other territory governed by an ally of the Crown'.

Twomey disagrees, arguing that in advising the Crown on its powers over colonial territories, the UK Ministers were entitled to take into account the UK's interests. ${ }^{148}$ Finnis agrees with Twomey arguing that prerogative legislation must be made in the interests of the UK and its dependencies as a whole, rather than the interest of the colony in question. ${ }^{149}$ I disagree. Although this constitutional theory may work in some places, faced with the express words of 'peace, order and good government of the territory', it cannot stand.

The dissenting judgement of Lord Atkins in Liversidge $v$ Anderson also concerned a point of statutory interpretation where the government sought to construe the words of a statute to the detriment of an individual's liberty:

I protest, even if I do it alone, against a strained construction put on words with the effect of giving an uncontrolled power of imprisonment to the Minister. To recapitulate: The words only have one meaning ... I know of only one authority which might justify the suggested method of construction. 'When I use a word' Humpty Dumpty said in a rather scornful tone 'it means just what I choose it to mean, neither more nor less. ${ }^{150}$

Swap 'exile' for 'imprisonment' and the same reasoning applies equally to Bancoult (2). Section 9 of the 2004 Order is void as exiling the inhabitants of a territory goes far beyond legislating for the peace, order and good government of the territory.

\section{Justiciability of Power}

Can the courts adjudicate upon the validity of prerogative legislative powers? Once again, there is a split in the jurisprudence. All judges in the House of Lords in Bancoult (2) ruled that the exercise of prerogative legislative powers was subject to judicial review. This flowed from previous case law which ruled that executive prerogative powers were amenable to judicial review. ${ }^{151}$ McBride welcomed this as an important step in establishing legal control over prerogative powers. ${ }^{152}$ However, the split occurs in considering whether the courts can undertake a substantive review of the merits of the legislation to see if it is actually for peace, order and good government. ${ }^{153}$ Daly describes this as the 'political question' doctrine. ${ }^{154}$ Lord Hoffman ruled that, once an Order was established as formally correct, the courts couldn't enquire into whether its objects could be said to be peace, order and good

\footnotetext{
${ }^{147}$ Bancoult (2) [47].

${ }^{148}$ Anne Twomey, The Chameleon Crown: The Queen and Her Australian Governors (Federation Press, 2006).

${ }^{149}$ John Finnis, 'Common Law Constraints: Whose Common Good Counts?' (Colloquium: The Common Law, the Royal Prerogative and Executive Legislation ,Cambridge, 19/1/2008).

${ }^{150}$ [1942] AC 206, 244, quoting Lewis Carroll, Through the Looking Glass (Macmillan, 1871).

${ }^{151}$ Council for Civil Service Unions v Minister for Civil Service (1985) AC 374.

152 Julie McBride, “"The Law Gives it and the Law May Take it Away”: The Repercussions of Bancoult (No.

2)' (2009) CSLR 190.

${ }^{153}$ Dominic McGoldrick, ‘The Boundaries of Justiciability’ (2010) ICLQ 981, 990.

${ }^{154}$ Paul Daly, 'Justiciability and the "Political Question” Doctrine’ (2010) PL 160.
} 
government. ${ }^{155}$ In Riel $v R$ it was held that peace, order and good government connoted 'the utmost discretion of enactment for the attainment of the objects pointed to'. ${ }^{156}$ The crux of this point is the division of power between judges, the legislature and the executive. Where parliament has properly passed a law, judges are loathe to overturn it on its merits. In the House of Lords it was stated that 'the sanction for inappropriate use of legislative power is political, not judicial'. ${ }^{157}$ As Calvert said

Legislatures, by and large, behave responsibly and even if they did not, it would be a brave court which would abrogate to itself a competence in judgement superior to that of the elected representatives of the people on the question of what constitutes 'good government'. ${ }^{158}$

There are two key points in response to this. Firstly, Lord Rodger said that 'the policy was, precisely, to trust the legislatures and to leave control not to the courts, but to the legislatures and, ultimately, to the electorates, both at home and, where appropriate, in the colony concerned'. ${ }^{159}$ But the 2004 Order was made by neither Parliament nor a colonial legislature, but by the executive. There is no democratic legitimacy available to be usurped by a judge. In any event, as Vaughan points out, ruling the 2004 Order void doesn't prevent the government from achieving its objectives by other means, such as an Act of Parliament. ${ }^{160}$ There is precedent, the Vagabonds Act 1597 exiled incorrigible and dangerous rogues and Irish, Scotch and Manx beggars.

Secondly, where there are words of limitation, judges are obliged to enquire if the limitation has been breached. This does not require a judge to ask 'is this law a good idea?' but 'does this law comply with its legal pre-requisites?' As Sedley LJ said in the Court of Appeal 'it is [the court's] constitutional function to decide whether what has been enacted is ... rationally and legally capable of providing for a colony's well being'. ${ }^{161}$ Elliot and Perreau-Saussine agree, arguing that such an enquiry 'hardly requires judicial engagement with the minutiae of the decision or making of fine judgements'.

The final point to be made in this section relates to judicial deference to executive decisions. Ginsburg regards 'constitutional review by courts as one safeguard against oppressive government'. ${ }^{163}$ Comella analysed judicial deference, 'a court is deferent towards parliament when it interprets the constitution in a way that is close to the interpretation implicitly relied upon by parliament'. ${ }^{164}$ One conclusion he drew was that a constitutional court was less likely to be deferential. The House of Lords is not a classed as a constitutional court. Judicial deference is clear from the historical analysis carried out by Swinfen. ${ }^{165}$ He quotes a UK civil servant as saying that 'but in practice the tendency has long been to consider Colonial Legislatures as legally competent to pass almost any law' ${ }^{166}$ Elliot and Perreau-

\footnotetext{
155 Bancoult (2) [51].

${ }^{156}$ (1885) 10 App Cas 675, 678.

157 Bancoult (2) [109].

${ }^{158}$ Calvert, 170-171.

${ }^{159}$ Bancoult (2) [98].

${ }^{160}$ Vaughan Lowe, 'Rule of International Law in English Courts' in Andenas.

${ }^{161}$ Bancoult (2) CA, 400.

162 Elliot \& Perreau-Saussine, 710.

${ }^{163}$ Ruth Ginsberg, 'Looking Beyond our Borders: The Value of a Comparative Perspective in Constitutional Adjudication’ (2003-04) 40 Idaho L Rev 1, 1.

${ }^{164}$ Victor Comella, 'Consequences of Centralizing Constitutional Review in a Special Court: Some Thoughts on Judicial Activisim’ (2003-04) 82 Tex L Rev 1705, 1722.

${ }_{165}$ DB Swinfen, Imperial Control of Colonial Legislation 1813-1865 (Clarendon Publishing, 1970).

166 Swinfen, 62.
} 
Saussine think that 'a measure of unnecessary and obfuscatory deference lives on in relation to the prerogative merely because it is the prerogative'. ${ }^{167}$

Lord Atkins thought this wrong - 'I view with apprehension the attitude of judges who on a mere question of construction when face to face with claims involving the liberty of the subject show themselves more executive minded than the executive'. ${ }^{168}$

\section{Precedent for Exercise of Prerogative}

In the Case of Proclamations the King sought to enforce his will by the issue of Royal Proclamations. ${ }^{169}$ The court held that 'The King hath no prerogative, but that which the law of the land allows him'. ${ }^{170}$ The same point was made in Entick $v$ Carrington 'if it is law, it will be found in our books. If it is not to be found there, it is not law'. ${ }^{171}$ The court ruled in $B B C \vee$ Johns $^{172}$ that the prerogative cannot be enlarged. These historical cases reflect the long power struggle between Crown and Parliament, with Parliament ever trying to curtail the power of an absolute monarch.

In recent times Lord Reid stated that

The prerogative is really a relic of a past age, not lost by disuse, but only available for a case not covered by statute. So I would think that the proper approach is a historical one: how was it used in former times and how has it been used in modern times? ${ }^{173}$

The modern statement of this principle is given by Bingham in Bancoult (2) when he said that 'the courts must conduct a historical enquiry to ascertain whether there is any precedent for the exercise of the power in the given circumstances'. ${ }^{174}$

What then is the historical precedent for a provision like s. 9 of the 2004 Order exiling a population from its homeland? Turning first to the case law, I have found no case suggesting that a person can be exiled by the prerogative. All I have found is cases stating the opposite. Coke cites two cases on exile. ${ }^{175}$ The King ordered Belknap to serve as a judge in Ireland. The King also ordered Sir Richard Pembrugh to serve as his deputy in Ireland. In both cases Coke found the orders unlawful. Fabrigas $v$ Mostyn concerned prerogative power in Minorca in the $18^{\text {th }}$ century. ${ }^{176}$ Minorca was ceded to the British. Governor Mostyn sought to banish Fabrigas, but the court ruled that the prerogative could not be used in this way. Forsyth considered whether Jesuits could be expelled from Maryland. ${ }^{177}$ If they were aliens, they could, but 'if they be her Majesty's natural born subjects, they cannot be banished from her Majesty's dominions'. ${ }^{178}$

Turning next to the eminent commentaries on English law, again the power of the Crown to exile is prohibited. Blackstone states that 'But no authority on earth, except the authority of Parliament, can send any subject of England out of the land against his will, no not even a

\footnotetext{
${ }^{167}$ Elliot \& Perreau-Saussine, 710.

${ }^{168}$ Liversidge, 244.

169 (1611) 12 Co Rep 74.

170 ibid 76.

171 (1765) 2 Wils 275.

172 (1965) 2 Ch 32.

${ }^{173}$ Burmah Oil Co. v Lord Advocate [1965] AC 75, 101.

174 [69].

${ }^{175}$ Edward Coke, Second Part of The Institutes of The Laws of England (Flesher and Young, 1642) 47.

176 (1773) 20 State Tr 175.

${ }^{177}$ William Forsyth, Cases and Opinions on Constitutional Law (Stevens \& Haynes, 1869).

${ }^{178}$ Ibid 36.
} 
criminal'. ${ }^{179}$ Holdsworth in his magisterial A History of the English Law agrees 'The Crown has never had a prerogative power to prevent its subjects from entering the Kingdom, or to expel them from it'. ${ }^{180}$ Coke, who represents the mother lode of commentaries on English law said that

By the law of the land no man can be exiled, or banished out of his native country, but either by authority of parliament, or in the case of abjuration for felony by the common law, and so when our books, or any record speaks of exile or banishment, other than in case of abjuration, it is intended to be done by authority of parliament. ${ }^{181}$

The reference to abjuration should be explained. It was an ancient right, related to the right of sanctuary. A felon could flee to a church, confess and do penitence in sackcloth in front of a sheriff, then go to a port carrying a crucifix. He would leave the realm, promising never to return, on pain of execution. Unfortunately for Julian Assange, abjuration is no longer law in the UK.

Craies carried out a detailed historical analysis entitled 'The Compulsion of Subjects to Leave the Realm'. ${ }^{182}$ He concluded that there was no 'royal claim to expel obnoxious subjects from the realm without trial and verdict; and subsequent attempts to bring people before the Royal Council were resisted and checked both in Plantagenet and Stuart times' ${ }^{183}$ This long-standing rule is related to the prohibition of exile in Magna Carta (see the next section). But it is a fact that there is no prerogative power to banish. As Lord Mance said 'it would be surprising if any precedent could be found for such a provision, and none has been shown'. ${ }^{184}$ Bingham agreed. ${ }^{185}$

There is no precedent for exile, section 9 cannot stand.

\section{Subservience of Prerogative Legislation to Parliamentary Legislation}

Prerogative legislation is inferior to parliamentary legislation. It cannot exist if Parliament has legislated on a subject. The modern exposition of this was in Attorney General $v$ De Keyser's Royal Hotel. ${ }^{186}$ In that case, the government expropriated private property for military purposes. If expropriation was carried out under the auspices of the statutory scheme, compensation was payable. However, the government argued that expropriation was actually done under the royal prerogative for the defence of the realm and hence no compensation was payable. The House of Lords ruled the government's argument absurd once Parliament has spoken, the government couldn't rely upon the prerogative. Lord Atkinson stated that once a statute is passed 'it abridges the Royal Prerogative while it is in force to this extent: that the Crown can only do the particular thing in accordance with the statutory provisions, and that its prerogative power to do that thing is in abeyance'. The House of Lords advanced this principle further in $R v$ Secretary of State for the Home Department ex parte Fire Brigades Union. ${ }^{187}$ The court held the prerogative was in abeyance

\footnotetext{
${ }^{179}$ William Blackstone, Commentaries on the Laws of England $\left(15^{\text {th }}\right.$ ed vol 1, 1809) 137.

${ }^{180}$ Vol X, 393.

${ }^{181}$ Coke, 47.

${ }^{182}$ William Craies (1890) 6 LQR 388.

${ }^{183}$ Craies, 393.

${ }^{184}$ Bancoult (2) [150].

${ }^{185}$ Ibid [70]

${ }^{186}$ [1920] AC 508

187 [1995] 2 AC 513.
} 
even though the statutory scheme had never been brought into force. Even though the statutory scheme was not actually a law yet, the fact that Parliament had spoken was enough to render the prerogative inoperable.

One modern case does deflect this principle from its trajectory in favour of proper parliamentary powers as against unaccountable and opaque prerogative powers. In $R v$ Secretary of State for the Home Department ex parte Northumbria Police Authority ${ }^{188}$ the court ruled that a prerogative power to maintain peace and order subsisted alongside specific statutory powers authorising police authorities to provide the police with certain equipment. Bradley criticised the reasoning in this case. ${ }^{189}$ In my view it is out of step with the progressive conception of democratic constitutionalism. Leigh also criticised the case arguing that

An alternative, and far preferable, approach would have been a cautious reading of the prerogative wherever a statute arose in the same field, thus forcing the executive to claim from the legislature specific authority to preserve the prerogative power where necessary. ${ }^{190}$

Harris considered the primacy of parliament so important that he argued that other nonprerogative powers ('third source powers') should also be residual, ie that they only subsist in the absence of parliamentary legislation. ${ }^{191}$

Regardless of these nuances, it is clear and it was accepted in Bancoult (2) that the prerogative is subservient to Parliamentary legislation. The relevant question is then, has Parliament legislated in this field such that the prerogative is in abeyance?

In my view, the answer to this question is categorically yes. Chapter 29 of Magna Carta 1215 reads

No freeman shall be taken, or imprisoned ... or exiled, or any otherwise destroyed ... but by the lawful judgement of his peers, or by the law of the land.

Magna Carta is the cornerstone of the British constitution and one of the most important documents in the struggle for democracy and civil liberties. Bingham cites it as his first milestone of the rule of law. He says that it 'expressed a clear rejection of unbridled, unaccountable royal power, an assertion that even the supreme power in the state must be subject to certain overriding rules'. ${ }^{192}$

Magna Carta states that exile is prohibited. Parliament (or at least its 1215 predecessor) has spoken. The prerogative power to exile is in abeyance. Two counter-arguments can be suggested. Firstly, that exile is acceptable if authorised 'by the law of the land' ie under section 9 of the 2004 Order. Secondly that Magna Carta doesn’t extend to BIOT.

Although superficially attractive, the first counter-argument fails on closer inspection.

Magna Carta was all about restricting the power of King John from riding roughshod over the rights of the Barons (the rights of the people were a later consideration). It was an attempt to limit royal power. It would be perverse to construe it as being subject to royal power. If the 'law of the land' includes 'the prerogative power to legislate' then the protection of Magna Carta is a phantasm. It is nonsensical to say that King John can't exile a person unless King

\footnotetext{
188 [1989] QB 26.

189 A Bradley, 'Police Powers and the Prerogative' [1998] PL 298.

${ }^{190}$ Ian Leigh, 'The Prerogative, Legislative Power, and the Democratic Deficit: The Fire Brigades Union Case' (1995 Web Journal of Current Legal Issues).

${ }^{191}$ Bruce Harris, 'The “Third Source” of Authority for Government Action Revisited' (2007) 123 LQR 225.

192 Bingham, 12.
} 
John exercises his prerogative power to exile the person. The 'law of the land' must mean a properly enacted law with democratic legitimacy separate from Crown powers.

Coke agrees with this analysis. He defines the original Latin version of 'per legem terrae' as meaning 'that is, by the Common Law, Statute Law or Custom of England'. ${ }^{193}$ He goes on to say that no-one can be imprisoned 'by petition or suggestion to the King, or to his Council'. ${ }^{194}$ As quoted in the previous section, Coke's firm view is that exile was only possible under an Act of Parliament.

The second counter-argument fails as there is express legislative provision applying Magna Carta to BIOT. Firstly, section 3 of the Courts Ordinance $1983^{195}$ states that, in relation to BIOT, 'the law to be applied as part of the law of the Territory shall be the law of England as from time to time in force in England'. There are some caveats to this provision, but none which would displace the application of Magna Carta. Secondly, the creation of BIOT in 1965 did not wipe out all previous laws in force under the Mauritian legal system. S. 15(1) of the 1965 Order states that all previous laws remain in force post-creation of BIOT. In both the 1884 and 1947 Digests of Mauritian Law there are several references to the remedy of habeas corpus being available in Mauritius. This remedy has long been regarded as stemming from Magna Carta. Therefore, as Magna Carta was in force in Mauritius pre-1965, it remained in force in BIOT post-1965. The government initially argued in Bancoult (1) that Magna Carta didn't extend to BIOT, but they subsequently resiled from this position. All the judges in Bancoult (2) regarded Magna Carta as applying in BIOT. Lord Rodger ruled that 'I proceed on the basis that [Magna Carta] applies and that no-one can be exiled from BIOT but by the law of the land'. ${ }^{196}$

If Magna Carta isn't regarded as sufficient to put the prerogative in abeyance, then the Human Rights Act 1998 should. The Act incorporated the terms of the European Convention on Human Rights into British law. The Convention protects the rights to liberty, security and private and family life. Exile is anathema to these rights. Parliament has spoken on this subject, therefore the prerogative is in abeyance and section 9 of the 2004 Order has no authority.

The counter-argument to this is the same as that for Magna Carta - that the Human Rights Act 1998 doesn't extend to BIOT. Article 56 of the Convention says that a state may make a declaration to extend the Convention to any territory for whose international relations it is responsible. The UK government made a declaration on 23 October 1953 that the Convention extended to Mauritius. It made a further declaration on 12 June 1969 that, in view of its independence, the extension to Mauritius lapsed. The declaration made on 30 June 1969 does not include BIOT in the list of territories to which the Convention extends. Lord Hoffman agreed with this counter-argument holding that the Convention 'applies to a political entity and not to the land which is from time to time comprised in its territory. BIOT has since 1965 been a new political entity to which the Convention has never been extended'. ${ }^{197}$

My response is that Lord Hoffman and the counter-argument are wrong for both a broad and a narrow reason. The broad reason is that it is constitutionally unrealistic to wipe the statute book clean and start with a blank page whenever there is accession, secession or partition leading to a constitutional or territorial change to a state. When Northern Ireland separated from the Republic of Ireland in 1920, the previous laws in force did not simply disappear overnight - they remained in force. Section 61 of the Government of Ireland Act 1920

\footnotetext{
${ }^{193}$ Coke, 46.

${ }^{194}$ Coke, 46.

${ }^{195}$ Another BIOT statute virtually impossible to track down.

${ }^{196}[86]$.

${ }^{197}$ Bancoult (2) [64].
} 
replicated the analogous provisions of s. 15 of the 1965 Order - all laws in force immediately before partition / secession remained in force afterwards. Obliterating the statute book upon territorial or constitutional change is a recipe for anarchy. It can't realistically be argued that BIOT was, immediately upon its creation, a land without laws.

The narrow reason for rejecting this counter-argument is that the various declarations made by the UK government don't in fact remove the application of the Convention to BIOT. When the first declaration was made extending the Convention to Mauritius, the term 'Mauritius' included the Chagos Islands. When the declaration was made withdrawing Mauritius from the Convention's ambit, it was because Mauritius was independent. But that 'Mauritius' did not include BIOT as BIOT had not attained independence. Therefore, the initial extension of the Convention to BIOT has never been withdrawn from BIOT.

There is a completely separate reason why the Convention applies to BIOT and therefore why the prerogative is in abeyance. Article 1 of the Convention states that 'The High Contracting Parties shall secure to everyone within their jurisdiction the rights and freedoms defined in Section I of this Convention' (my emphasis). This is a free-standing ground for application of the Convention. By definition, BIOT is within the jurisdiction of the UK - the UK has complete executive, legislative and judicial control of the territory. Therefore there is an obligation to comply with the Convention. The effectiveness of Article 1 was accepted by the European Court of Human Rights in the case of Ocalan $v$ Turkey. ${ }^{198}$ In that case, Turkish forces took Ocalan into their custody in Kenya. The court nevertheless held that Art 1 was engaged as Ocalan was within their jurisdiction even though he was thousands of miles from Turkey. In R (Al Skeini) v Secretary of State for Defence the House of Lords ruled on this point. ${ }^{199}$ They found that the fact that a person was in the custody of British soldiers in Iraq meant that Art 1 of the Convention and also the Human Rights Act 1998 was engaged.

In dealing with an analogous international treaty, Capps makes similar points to those I have made above. He argues that the UK cannot disclaim responsibility for BIOT under the International Covenant on Civil and Political Rights as any reservation purporting to exclude BIOT would be invalid. ${ }^{200}$

\section{Extinguishment of Prerogative upon Establishment of Colonial Legislative Assembly}

The specific power of the Crown to legislate for conquered territories can also be extinguished by the establishment of a legislative assembly in that territory. Wray states that 'if the Crown grants to a conquered territory a representative legislative body, without reserving to itself the power to legislate, that power is no longer exercisable'. ${ }^{201}$ This was the precise ratio in the seminal case of Campbell $v$ Hall. That case concerned Grenada, conquered in 1762 and ceded to the British in 1763. The King established a parliament there and then subsequently attempted to impose a tax. The court ruled that he had no power to do so. Holdsworth explained the ratio as follows

Though the King had power to levy such a duty by his prerogative in a conquered colony, he had, by the grant of representative institutions, put Grenada into the

\footnotetext{
198 (2005) 41 EHRR 45.

199 [2007] UKHL 26

${ }^{200}$ Patrick Capps, 'Responsibility for Acts in Violation of International Law in BIOT' (Colloquium: The

Common Law, the Royal Prerogative and Executive Legislation, Cambridge, 19/1/2008).

${ }^{201}$ Wray, 157.
} 
position of a settled colony; with the result that such a duty could only be imposed either by an Act of the Assembly or by Act of Parliament. ${ }^{202}$

The Privy Council followed this ruling in Re Lord Bishop of Natal. ${ }^{203}$ That case concerned the prerogative power to create a new bishopric in South Africa. The Court held that

After the establishment of an independent legislature in the Settlements of the Cape of Good Hope and Natal, there was no power in the Crown by virtue of its Prerogative [to establish a bishopric] ... After a colony or settlement has received legislative institutions the Crown ... stands in the same relation to that colony or settlement as it does to the United Kingdom. ${ }^{204}$

The unanswered question is whether the prerogative power is extinguished in these circumstances, or is merely in abeyance ready to be revived when needed. Like most questions about vague and uncodified prerogative powers, it is hard to be canonical with the answer. In my opinion, democratic power is incompatible with royal power and if the Crown has given away its right to legislate, it cannot subsequently take it back. It could be argued that this creates a legislative vacuum if a local legislature is prorogued and no prerogative power remains. However, the vacuum can very easily be filled by relying on the superior power of Parliament to legislate for the territory.

This argument can then be applied to the Chagos Islands. According to Matthew Lange, Mauritius has had a Council of Government since $1825 .^{205}$ He described it as the 'official legislative branch of the colony'. ${ }^{206}$ In 1947 the Council became the Legislative Assembly with 12 members appointed by the Governor and 19 elected. In 1958, 40 members were elected by universal suffrage.

It is therefore indisputable that the Crown ceded its prerogative legislative powers to the Mauritius Legislative Assembly and that, before detachment in 1965, that Assembly had power to legislate for the Chagos Islands. Therefore, it is submitted that the prerogative power to legislate for BIOT expired. Once expired, it could not then be revived in 1965. However, this argument runs into difficulties if the establishment of the local legislature could be construed as including a reservation preserving the prerogative power. There is also an argument that the Crown always retains a prerogative power to alter a colony's constitution.

\section{Repugnancy of Colonial Legislation to English Law}

One of the key rulings in Campbell $v$ Hall was that the Crown 'cannot make any new change contrary to fundamental principles' of English law. ${ }^{207}$ This established a principle that colonial laws (including those made by the prerogative) would be void if repugnant to the fundamental principles of English law. For example, the court in Fabrigas $v$ Mostyn considered whether torture could be used in Minorca and ruled that it couldn't - 'the constitution of this country put an end to that idea' ${ }^{208}$ Jenkyns wrote that 'any laws contrary

\footnotetext{
${ }^{202}$ Holdsworth, Vol XI, 237.

203 [1864-65] 3 Moo PCNS 115.

204 Ibid 148.

${ }^{205}$ Lineages of Despotism and Development: British Colonialism and State Power (University of Chicago Press, 2009).

${ }^{206}$ Lange, 76.

207209.

${ }^{208}$ Col. 181.
} 
to the fundamental principles of English law, eg torture, banishment or slavery are ipso facto abrogated'. ${ }^{209}$

In some ways, this is a laudable principle and the courts could have developed a list of 'fundamental principles'. However, in practice the principle was too vague and caused uncertainty. Finnis quotes colonial lawyers stating that it would be impossible to lay down rules to distinguish between fundamental and non-fundamental English laws. Holdsworth said that it 'left it quite uncertain what laws could be deemed to be fundamental'. ${ }^{210}$ Things came to a head in the Australian case of McEllister v Fenn ${ }^{211}$ where the judge called into question the validity of large swathes of colonial legislation. The Parliament of South Australia launched an enquiry. ${ }^{212}$ Whilst recognising a theoretical problem with lack of precision, their view was that 'no practical difficulty was likely to arise from the doctrine of repugnancy because it was unlikely that the legislature would pass, or the Governor or the Crown would sanction, a law repugnant to fundamental principles'. ${ }^{213}$

Nevertheless, the Imperial Parliament decided to act to prevent this problem arising again. They did so by passing the Colonial Laws Validity Act 1865. This replaced the vague 'repugnant to fundamental principles of English law' with the more concrete 'repugnant to an Act of Parliament'. Keith stated that 'the essential feature of this measure is that it abolished once and for all the vague doctrine of repugnancy to the principles of English law as a source of invalidity of any Act'. ${ }^{214}$ The court in Liyanage $v R$ confirmed that the Act did not leave in existence 'a fetter of repugnancy to some vague unspecified law of natural justice'. ${ }^{215}$ Professor Finnis agreed, 'its purpose will have been to abolish the whole repugnancy doctrine in Campbell $v$ Hall' ${ }^{216}$

Although some of the other judges in Bancoult (2) did mention fundamental principles, it is submitted that Lord Rodger was correct in his analysis that the doctrine had been superseded by the 1865 Act. To use Finnis' colourful phrase, it isn't enough if a colonial law falls within a parade of horibilia, it will only be void if repugnant to an Act of Parliament. ${ }^{217}$

What then is the scheme of the Colonial Laws Validity Act 1865? In s. 1 it defines colonial law to include laws passed by colonial legislatures as well as laws passed under the prerogative. It also provides that an Act of Parliament extends to a colony either by express words or necessary intendment. Section 2 is the key provision, it states that a colonial law is void if it is repugnant to the provisions of any Act of Parliament extending to a colony. S. 3 nails the lid on the coffin of the 'fundamental principles' principle by saying that s. 2 is the only ground for repugnancy. The Act is straightforward and was effective.

It only remains to apply it to the 2004 Order. It is here that I part company with Lord Rodger. For the reasons expounded upon in the previous section, it is my contention that both Magna Carta and the Human Rights Act apply in BIOT. Banishment is repugnant to both these statutes. Therefore, s. 9 of the 2004 Order is void.

\footnotetext{
${ }^{209}$ Henry Jenkyns, British Rule and Jurisdiction Beyond the Seas (Clarendon Press, 1902) 6.

${ }^{210}$ Holdsworth, Vol XIV, 346.

211 (1861) SASC.

212 Parliamentary Papers (vol xxxvii, 1863).

${ }^{213}$ Holdsworth, Vol XIV 346.

${ }^{214}$ AB Keith, The Sovereignty of British Dominions (Macmillan, 1929).

215 [1967] 1 AC 259, 284.

${ }^{216}$ Finnis, [6].

${ }^{217}$ Finnis, [13].
} 


\section{Chapter 5 - Conclusion}

The Chagossians were exiled from their homeland by prerogative legislation - legislation made, not by a legislature but by the executive. I have sought to show that the 2004 Order is bad law because it is of low quality, is inaccessible and is ultra vires.

I have shown that the 2004 Order is of low quality when measured by Xanthaki's criteria. It is not clear, precise or unambiguous. It is not written in gender neutral or plain language. Its title is disingenuous.

If the Order had been made as an Act of Parliament, it is submitted that most of these defects would have been removed. It would have been drafted by trained legislative counsel familiar with the principles of sound legislative drafting. Proper scrutiny would have improved quality. It would correctly have been entitled the Chagos Islands (Exile) Act.

I have shown that the inaccessibility of the 2004 Order seriously undermines its legitimacy. Accessibility is fundamental to the legality of a law. A law which is only accessible by literally trawling through dusty shelves in the basement of a London law library is not a good law. If the law had been made properly, rather than by the prerogative, accessibility would have vastly improved. It would be on the statute book, on Parliament's website, on the official legislation website and available on multiple databases. Cohn states that prerogative orders are 'less visible and accessible and provide a weaker basis for accountability and review processes' ${ }^{218}$ It is hard to argue with her view that this is precisely what makes this mode of law-making attractive to government.

I have shown that there is no prerogative power to make legislation of this sort. Exile cannot be said to promote peace, order and good governance and there is no precedent for its use. In fact, it goes against fundamental legislation such as Magna Carta and the Human Rights Act 1998. If the Order had instead been made by Parliament, then these objections on vires would have largely fallen away. Sovereignty of Parliament means that Parliament is largely free to legislate as it please (although there still could be human rights challenges).

Although the 2004 Order may be the nadir of bad law, I have shown that other prerogative legislation also suffers from defects in terms of quality and accessibility. As Cohn summarises, prerogative legislation allows government to make laws 'without passing the cumbersome legislative process, to design and apply rules without necessarily publishing them, thereby evading subjection to accountability mechanisms'. ${ }^{219}$ Moules also attacks prerogative legislation on this ground, as an attempt by the executive to deny parliamentary and judicial scrutiny simply by choosing a particular mode of enactment. ${ }^{20}$

Parliamentarians have turned their minds to this issue and have spoken clearly against the policy. Discussing the Chagossians, Jeremy Corbyn MP said

\footnotetext{
${ }^{218}$ Margit Cohn, 'Judicial Review of Non-Statutory Executive Powers after Bancoult: a Unified Anxious Model’ [2009] PL 260, 262.

${ }^{219}$ Cohn, 265.

${ }^{220}$ Richard Moules, 'Judicial Review of Prerogative Orders in Council: Recognising the Constitutional Reality of Executive Legislation’ (2008) 67 CLJ 12.
} 
'The Prime Minister's Office has inherited the power of the royal prerogative and this can and is used to bypass Parliament. It is high time that all prime ministerial decisions were brought under parliamentary scrutiny. ${ }^{\text {,21 }}$

As has been demonstrated in relation to the Chagos Islands, prerogative law-making is the paradigm of bad law-making. In my opinion, this law is so fundamentally flawed, so oppressive and draconian that it should never have been made.

${ }^{221}$ Website of Jeremy Corbyn MP < http://www.jeremycorbyn.org.uk/?p=1060 $>$ accessed on 22/8/2012. 


\section{Appendix - Copies of BIOT Gazette in British Law Libraries}

\begin{tabular}{|c|c|c|c|c|c|}
\hline Gazette & Issue & $\begin{array}{l}\text { Institute of } \\
\text { Advanced Legal } \\
\text { Studies Library }\end{array}$ & $\begin{array}{l}\text { British } \\
\text { Library }\end{array}$ & $\begin{array}{l}\text { Squire Law } \\
\text { Library }\end{array}$ & $\begin{array}{l}\text { Cambridge } \\
\text { University } \\
\text { Library }\end{array}$ \\
\hline 1965 & & & Yes & & Yes \\
\hline 1966 & & Deficient & & & Yes \\
\hline 1967 & & & & & Yes \\
\hline \multicolumn{6}{|l|}{1968} \\
\hline \multicolumn{6}{|l|}{1969} \\
\hline \multicolumn{6}{|l|}{1970} \\
\hline \multicolumn{6}{|l|}{1971} \\
\hline \multicolumn{6}{|l|}{1972} \\
\hline \multicolumn{6}{|l|}{1973} \\
\hline \multicolumn{6}{|l|}{1974} \\
\hline \multicolumn{6}{|l|}{1975} \\
\hline \multicolumn{6}{|l|}{1976} \\
\hline \multicolumn{6}{|l|}{1977} \\
\hline \multicolumn{6}{|l|}{1978} \\
\hline \multicolumn{6}{|l|}{1979} \\
\hline \multicolumn{6}{|l|}{1980} \\
\hline \multicolumn{6}{|l|}{1981} \\
\hline 1982 & & & Yes & & \\
\hline \multicolumn{6}{|l|}{1983} \\
\hline \multicolumn{6}{|l|}{1984} \\
\hline \multicolumn{6}{|l|}{1985} \\
\hline \multicolumn{6}{|l|}{1986} \\
\hline \multicolumn{6}{|l|}{1987} \\
\hline \multicolumn{6}{|l|}{1988} \\
\hline \multicolumn{6}{|l|}{1989} \\
\hline \multicolumn{6}{|l|}{1990} \\
\hline \multicolumn{6}{|l|}{1991} \\
\hline 1992 & & & Yes & & \\
\hline \multirow{5}{*}{$\frac{1993}{1994}$} & & Yes & Yes & & \\
\hline & 1 & Yes & Yes & & \\
\hline & 2 & Yes & Yes & & \\
\hline & 3 & Yes & Yes & & \\
\hline & 4 & & Yes & & \\
\hline \multirow[t]{2}{*}{1995} & 1 & Yes & Yes & & \\
\hline & 2 & Yes & Yes & & \\
\hline 1996 & 1 & Yes & Yes & & \\
\hline & 2 & & Deficient & & \\
\hline 1997 & 1 & Yes & Deficient & & \\
\hline & 2 & Yes & Yes & & \\
\hline 1998 & 1 & Yes & Yes & & \\
\hline & 2 & Yes & Yes & & \\
\hline
\end{tabular}


F1059

\begin{tabular}{|c|c|c|c|c|c|}
\hline Gazette & Issue & $\begin{array}{l}\text { Institute of } \\
\text { Advanced Legal } \\
\text { Studies Library }\end{array}$ & $\begin{array}{l}\text { British } \\
\text { Library }\end{array}$ & $\begin{array}{l}\text { Squire Law } \\
\text { Library }\end{array}$ & $\begin{array}{l}\text { Cambridge } \\
\text { University } \\
\text { Library }\end{array}$ \\
\hline & 3 & Yes & Yes & & \\
\hline \multirow[t]{2}{*}{1999} & 1 & Yes & Yes & & \\
\hline & 2 & Yes & Yes & & \\
\hline \multirow[t]{2}{*}{2000} & 1 & Yes & Yes & & \\
\hline & 2 & Yes & Yes & & \\
\hline \multirow[t]{2}{*}{2001} & 1 & Yes & Yes & & \\
\hline & 2 & Yes & Yes & & \\
\hline \multirow[t]{2}{*}{2002} & 1 & Yes & Yes & & \\
\hline & 2 & & Deficient & & \\
\hline \multirow[t]{2}{*}{2003} & 1 & Yes & Yes & & \\
\hline & 2 & & Deficient & & \\
\hline \multirow[t]{2}{*}{2004} & 1 & Yes & Yes & & \\
\hline & 2 & Yes & Yes & & \\
\hline \multirow[t]{2}{*}{2005} & 1 & Yes & yes & & \\
\hline & 2 & & & Yes & \\
\hline \multirow[t]{2}{*}{2006} & 1 & Yes & Yes & Yes & \\
\hline & 2 & Yes & Yes & Yes & \\
\hline \multirow[t]{2}{*}{2007} & 1 & Yes & Yes & Yes & \\
\hline & 2 & & & Yes & \\
\hline \multirow[t]{2}{*}{2008} & 1 & Yes & Yes & Yes & \\
\hline & 2 & Yes & Yes & Yes & \\
\hline 2009 & & Yes & yes & Yes & \\
\hline 2010 & & & Yes & Yes & \\
\hline \multirow[t]{2}{*}{2011} & 1 & Yes & Claimed & & \\
\hline & 2 & & Claimed & & \\
\hline
\end{tabular}




\section{Bibliography}

Andenas, M \& Fairgrieve, D (eds) Tom Bingham and the Transformation of the Law: A Liber Amicorum (Oxford University Press, 2009)

Anthony, K ‘The Public Access to Legislation Project: Served with Accompaniments’ (2008) 16 Austl L Libr 21

Auchmuty, R ‘Whatever happened to Miss Bebb? The Law Society and Women’s Legal History’ (2011) 31 Legal Studies 199

Bennion, F ‘The Readership of Legal Texts’ (1993) 27 April, Clarity 1

Bennion, F Bennion on Statutory Interpretation ( $5^{\text {th }}$ edition, Lexisnexis 2008)

Bingham, T The Rule of Law (Penguin, 2011)

Blackstone, W Commentaries on the Laws of England (15 ${ }^{\text {th }}$ edition vol 1, 1809)

Bradley, A ‘Police Powers and the Prerogative’ [1998] PL 298

Browning, A English Historical Documents Vol VIII ( Eyre \& Spottiswoode, 1953)

Butt, P ‘Modern Legal Drafting’ (2002) 23 SLR 12

Calvert, H Constitutional Law in Northern Ireland: A Study in Regional Government (Stevens \& Sons, 1968)

Capps, P ‘Responsibility for Acts in Violation of International Law in BIOT’ (Colloquium: The Common Law, the Royal Prerogative and Executive Legislation, Cambridge, 19/1/2008) Carr, C Delegated Legislation (Cambridge University Press, 1921)

Carroll, L Through the Looking Glass (Macmillan, 1871)

Christie, G 'Vagueness and Legal Language’ (1963-64) Minn L Rev 885

Cohn, M 'Judicial Review of Non-Statutory Executive Powers after Bancoult: a Unified Anxious Model’ [2009] PL 260

Coke, E Second Part of The Institutes of The Laws of England (Flesher and Young, 1642) Comella, V 'Consequences of Centralizing Constitutional Review in a Special Court: Some Thoughts on Judicial Activisim’ (2003-04) 82 Tex L Rev 1705

Cormacain, R ‘A Plain Language Case Study: Business Tenancies (Northern Ireland) Order 1996’ (2012) The Loophole 33

Craies, W ‘The Compulsion of Subjects to Leave the Realm’ (1890) 6 LQR 388

Daly, P ‘Justiciability and the “Political Question” Doctrine’ (2010) PL 160

Del Duca, L 'Is it Time for a Model Set of Drafting Principles’ (2000 - 01) 105 Dick L Rev 205 
Department of Justice, The Governance of Britain (Cm7170, 2007)

Dicey, AV Introduction to the Study of the Laws of the Constitution ( $8^{\text {th }}$ edition, 1915)

Dickerson, R ‘The Diseases of Legislative Language’ (1964) 1 Harv J on Legis 5

Donelan, E 'European Approaches to Improving Access to and Managing the Stock of Legislation’ (2009) 30 SLR 147

Eagleson, R Writing in Plain Language (Commonwealth of Australia, 1990)

Elkins, Z et al, The Endurance of National Constitutions (Cambridge University Press, 2009)

Elliot, M \& Perreau-Sausinne, A 'Pyrrhic Public Law: Bancoult and the Sources, Status and Content of Common law Limitations on Prerogative Power’ (2009) PL 697

Eshelman, M ‘New Pitcairn Islands Constitution: Strong, Empty Words for Britain’s Smallest Colony’ (2012) 24 Pace Int'l L Rev 21

Finer, S et al, Comparing Constitutions (Clarendon Press, 1995)

Finer, S Five Constitutions (Humanities Press, 1979)

Finnis, J ‘Common Law Constraints: Whose Common Good Counts?’ (Colloquium: The Common Law, the Royal Prerogative and Executive Legislation ,Cambridge, 19/1/2008) Foreign Affairs Committee, Seventh Report: Overseas Territories (HC 2007-08, HC 147-I) Foreign and Commonwealth Office, Partnership for Progress and Prosperity: Britain and the Overseas Territories (Cm 4264, 1999)

Forsyth, W Cases and Opinions on Constitutional Law (Stevens \& Haynes, 1869)

Fraser, G 'In Praise of Ambiguity’ (2000) Jan - Feb Policy Options 21

Ginsberg, R 'Looking Beyond our Borders: The Value of a Comparative Perspective in Constitutional Adjudication’ (2003-04) 40 Idaho L Rev 1

Gleeson, M 'Courts and the Rule of Law’ (Melbourne University, 7 November 2001)

Gobbi, M 'Making sense of Ambiguity: Some Reflections on the use of Treaties to Interpret Legislation in New Zealand' (2002) 23 SLR 47

Greenberg, D Craies on Legislation ( $9^{\text {th }}$ edition, Sweet and Maxwell, 2008)

Greene, W Digest of the Reported Criminal Jurisprudence of the Supreme Court of Mauritius 1843 -1883 (Port Louis, 1884)

Harris, B ‘The “Third Source” of Authority for Government Action Revisited’ (2007) 123 LQR 225

Hendry, I and Dickson, S British Overseas Territory Law (Hart Publishing, 2011)

Hill, W 'A Need for the Use of Non-Sexist Language in the Courts' (1992) 49 Wash and Lee L Rev 275

Holdsworth, W A History of the Law of England Volume X (Methuen, 1938) 
Holdsworth, W A History of the Law of England Volume XI (Methuen, 1938)

Holdsworth, W A History of the Law of England Volume XIV (Methuen, 1964)

Hughes, L Digest of the Reported Decisions of the Supreme Court of Mauritius 1861-1901 (Central Printing Establishment, 1905)

Jenkyns, H British Rule and Jurisdiction Beyond the Seas (Clarendon Press, 1902)

Johnson, P 'Legislative Drafting Practices and Other Factors Affecting the Clarity of Canada’s Laws' (1991) 12 SLR 1

Jones, B 'Transatlantic Perspectives on Humanised Public Law Campaigns: Personalising and Depersonalising the Legislative Process’ (2012) 6 Legisprudence 57

Keith, AB The Sovereignty of British Dominions (Macmillan, 1929)

Kent, B Book Review: Diego Garcia Island of Shame (2009)

Keyes, J 'Perils of the Unknown - Fair Notice and the Promulgation of Legislation' (1993)

25 Ottawa L Rev 579

Kimble, J 'Answering the Critics of Plain Language' (Plain Language Association International, 2003)

Lalouette, G A Digest of the Decisions of the Supreme Court of Mauritius 1926 -1945 (Eliel Felix, 1947)

Lange, M Lineages of Despotism and Development: British Colonialism and State Power (University of Chicago Press, 2009)

Lawn, G 'Improving Public Access to Legislation: The New Zealand Experience so far' (2004) 6 UTS L Rev 49

Leigh, I 'The Prerogative, Legislative Power, and the Democratic Deficit: The Fire Brigades Union Case' (1995 Web Journal of Current Legal Issues)

Lord Hewart, The New Despotism (Ernest Benn, 1929)

Lord Simon, ‘The Renton Report - Ten Years On’ (1985) SLR 133

Lowe, V 'Rule of International Law in English Courts' in Andenas \& Fairgrieve Mackinlay, J 'Syntactic Discontinuity in the Language of UK and EU Legislation' accessed at <http://www.esp-world.info/index.html $>$ on 1/8/2012

Madeley, J Diego Garcia: A Contrast to the Falklands (Minority Rights Group Report No. $54,1985)$

McBride, J ، “The Law Gives it and the Law May Take it Away”: The Repercussions of Bancoult (No. 2)’ (2009) CSLR 190

McGoldrick, D ‘The Boundaries of Justiciability’ (2010) ICLQ 981

Moules, R 'Judicial Review of Prerogative Orders in Council’ (2009) CLJ 14 
Moules, R 'Judicial Review of Prerogative Orders in Council: Recognising the Constitutional Reality of Executive Legislation’ (2008) 67 CLJ 12

Mowat, C A Plain Language Handbook for Legal Writers (Carswell, 1998)

Nairac, G Digest of the Mauritius Law Reports 1902-1925 (PG Bumstead, 1927)

Orwell, G 1984 (Secker \& Warburg, 1949)

Paine, T Common Sense and Other Writings (Modern Library, 2003)

Perreau-Sausinne, A ‘British Acts of State in English Courts’ (2007) 78 BYIL 176

Petersson, S ‘Gender Neutral Drafting: Recent Commonwealth Developments’ (1990) 20 SLR 35

Poole, T 'United Kingdom: The Royal Prerogative’ (2010) 8 IJCL 146

Plender, R International Migration Law ( $2^{\text {nd }}$ edition, Martinus Nijhoff, 1988)

Raworth, P Consitutions of Dependencies and Territories (Oceana, 2002)

Report of the Renton Committee on the Preparation of Legislation (1975, Cmnd. 6053)

Roberts-Wray, K Commonwealth and Colonial Law (Stevens \& Sons, 1966)

Ronald, J 'Publication of Federal Administrative Legislation' (1938) 7 Geo Wash L Rev 52

Sales, P ‘Bancoult (2) and Legitimate Expectation’(Colloquium: The Common Law, the Royal Prerogative and Executive Legislation ,Cambridge, 19/1/2008)

Schweikart, D ‘Gender Neutral Pronoun Redefined’ (1998-99) 20 Women’s Rts L Rep 1 Select Committee on Public Administration, Taming the Prerogative (HC 2003-04, 422) SIGMA, Law Drafting and Regulatory Management in Central and Eastern Europe SIGMA Papers No. 18

Snoxell, D 'Political Context (the Bancoult case) and Possible Solutions' (Colloquium: The Common Law, the Royal Prerogative and Executive Legislation, Cambridge, 19/1/2008) Stefanou, C and Xanthaki, H (eds), Drafting Legislation: A Modern Approach (Ashgate, 2008)

Suetonius, Lives of the 12 Caesars (Alexander Thomson translator, 1883)

Sullivan, R ‘Implications of Plain Language Drafting’ (2000) 22 SLR 145

Swinfen, DB Imperial Control of Colonial Legislation 1813-1865 (Clarendon Publishing, 1970)

Tanner, E 'Legislating to Communicate: Trends in Drafting Commonwealth Legislation' (2002) 24 Sydney L Rev 529

Thomas, R ‘Plain English and the Law’ (1985) SLR 139

Thornton, G Legislative Drafting ( $4^{\text {th }}$ edition, Butterworths, 1996) 
Thring, H Practical Legislation: The Composition and Language of Acts of Parliament and Business Documents (John Murrary, 1902)

Tomkins, A ‘Magna Carta, Crown and Colonies’ (2001) PL 571

Turnbull, M ‘Clear Legislative Drafting: New Approaches in Australia’ (1990) 11 SLR 161

Turpin, C and Tomkins, A British Government and the Constitution (Cambridge University Press, 2007)

Twomey, A The Chameleon Crown: The Queen and Her Australian Governors (Federation Press, 2006)

Unknown, ‘Avoidance of Sexist Language in Legislation’ (1985) 11 Commw L Bull 590

Vine, D, Island of Shame: The Secret History of the US Military Base at Diego Garcia (Princeton University Press, 2009)

W Murphy, 'Constitutions, Constitutionalism and Democracy’ in Douglas Greenberg et al (eds) Constitutionalism and Democracy: Transitions in the Contemporary World (Oxford University Press, 1993)

Warbrick, C 'Who Calls the Shots? Defence, Foreign Affairs, International Law and the Governance of Britain’ 548 in Andenas \& Fairgrieve

Watson-Brown, A 'Defining “Plain English” as an Aid to Legal Drafting' (2009) 30 SLR 85 Wilde, O The Picture of Dorian Grey (Penguin Classics, 2006)

Xanthaki, H 'On Transferability of Legislative Solutions: The Functionality Test' in Stefanou and Xanthaki 


\section{Table of Cases}

\section{United Kingdom}

Attorney General v De Keyser's Royal Hotel [1920] AC 508

Bancoult v Secretary of State for Foreign and Commonwealth Affairs [2008] UKHL 61

Bancoult v Secretary of State for Foreign and Commonwealth Affairs [2001] QB 1067

Bancoult v Secretary of State for Foreign and Commonwealth Affairs [2006] EWHC 1038 (Admin)

Bancoult v Secretary of State for Foreign and Commonwealth Affairs [2008] QB 365

BBC v Johns (1965) 2 Ch 32

Bebb v Law Society [1914] 1 Ch 286

Black Clawson v Papierwerke Waldhof (1975) AC 591

Blankard v Galdy (1696) 1 Salk 411

Burmah Oil Co. v Lord Advocate [1965] AC 75

Campbell v Hall (1774) 1 Cowp. 204

Case of Proclamations (1611) 12 Co Rep 74

Council for Civil Service Unions v Minister for Civil Service (1985) AC 374

Duffy v Minister of Labour and National Insurance [1962] NI 6

Entick v Carrington (1765) 2 Wils 275

Fabrigas v Mostyn (1773) 20 State Tr 175

Gallagher v Lynn [1938] NI 21

Ibralebbe v R [1964] AC 900

Liversidge v Anderson [1942] AC 206

Liyanage v R [1967] 1 AC 259

R (Al Skeini) v Secretary of State for Defence [2007] UKHL 26

R v Chambers [2008] EWCA Crim 2467

R v Secretary of State for the Home Department ex parte Fire Brigades Union [1995] 2 AC 513

R v Secretary of State for the Home Department ex parte Northumbria Police Authority [1989] QB 26

Riel v R (1885) 10 App Cas 675

Spillers v Cardiff Assessment Committee [1931] 2 KB 21

Ulster Transport Authority v James Brown [1953] NI 79 
F1059

ZL and VL v Secretary of State [2003] EWCA Civ 25

\section{Australia}

Building Construction Employees and Builders' Labourers Federation of New South Wales V Minister for Industrial Relations (1986) 7 NSW LR 372

McEllister v Fenn (1861) SASC

Union Steamship Co of Australia v King (1988) 166 CLR 1

\section{Mauritius}

Colonial Government v Vitry (1899) 1861-1901 Mauritian Digest 53

\section{United States of America}

Grayned v Rockford 408 US 104 (1972)

\section{Canada}

Watson v Lee (1979) 26 ALR 461

Hodge v R (1883) 9 App Cas 117

\section{India}

R v Burah (1883) 9 App Cas 889

\section{South Africa}

Re Lord Bishop of Natal [1864-65] 3 Moo PCNS 115

\section{European Court of Human Rights}

Sunday Times v UK (1979) 2 EHRR 245

Ocalan v Turkey (2005) 41 EHRR 45 


\section{Table of Legislation}

\section{United Kingdom}

British Settlements Act 1887

Civil Service (Special Advisers) Bill

Colonial Laws Validity Act 1865

Companies Act 2006

Constitutional Reform and Governance Act 2010

Freedom of Information Act 2000

Government of Ireland Act 1920

Human Rights Act 1998

Magna Carta 1215

Standing Orders of the Scottish Parliament

Statutory Instruments Act 1946

Statutory Rules (Northern Ireland) Order 1979

Vagabonds Act 1597

\section{United Kingdom - Prerogative Orders}

Public Appointments (Amendment) Order 2009

Diplomatic Service (Amendment) Order 2009

Reprisal Orders 1915, 1917

Requisition of Ships Order 1982

Civil Service Commissioners (Northern Ireland) Order 1999

Civil Service Commissioners (Northern Ireland) (Amendment) Order 2003

Civil Service Commissioners (Northern Ireland) (Amendment) Order 2007

\section{British Indian Ocean Territory}

British Indian Ocean Territories Order 1965

British Indian Ocean Territory (Constitution) Order 2004

British Indian Ocean Territory (Immigration) Order 2004

British Overseas Territory Order 1976

Courts Ordinance 1983 
F1059

Immigration Ordinance 1971

Immigration Ordinance 2000

\section{Mauritius}

Mauritius Independence Order 1968

\section{International}

European Convention on Human Rights

International Covenant on Civil and Political Rights 